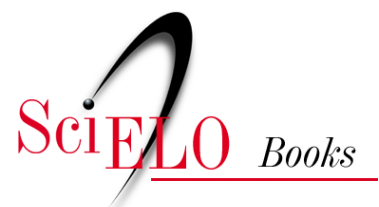

\title{
A Abrasco em Imagens
}

\author{
Nísia Trindade Lima \\ José Paranaguá de Santana \\ Carlos Henrique Assunção Paiva \\ (orgs.)
}

LIMA, N.T., SANTANA, J.P., and PAIVA, C.H.A., orgs. A Abrasco em Perspectiva: olhares dos presidentes. In: Saúde coletiva: a Abrasco em 35 anos de história [online]. Rio de Janeiro: editora FIOCRUZ, 2015, pp. 279-312. ISBN: 978-85-7541-590-0. Available from: doi:

$\underline{10.7476 / 9788575415900.0015}$. Also available in ePUB from:

http://books.scielo.org/id/q4gzb/epub/lima-9788575415900.epub.

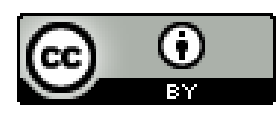

All the contents of this work, except where otherwise noted, is licensed under a Creative Commons Attribution 4.0 International license.

Todo o conteúdo deste trabalho, exceto quando houver ressalva, é publicado sob a licença Creative Commons Atribição 4.0.

Todo el contenido de esta obra, excepto donde se indique lo contrario, está bajo licencia de la licencia Creative Commons Reconocimento 4.0. 


\section{A Abrasco em Imagens}

nstituições são feitas por gente, que muitas vezes deve a elas, a quem legou toda uma vida, uma relação de gratidão e dádiva. As instituições, por vezes, retribuem a dádiva e a dedicação na forma de seu reconhecimento pelos anos legados e pelas lutas que foram capazes de trazer, ao colo institucional, tantos corações e mentes apaixonados.

Nesse aspecto, as instituições representam o ponto de encontro entre pessoas e suas paixões. Com a Associação Brasileira de Saúde Coletiva (Abrasco), esse processo não foi diferente. Desde sua fundação, em 1979, ela foi capaz de reunir em torno de si personagens que, muitas vezes por seu intermédio, seriam cruciais na trajetória das saúdes pública e coletiva brasileiras. São rostosque, com o passar do tempo, se modificaram, mas cujoímpetoe dedicação permanecem. Personagens que perseguiram, desde os primórdios da instituição, ideais que se situam no território da justiça social e da melhoria das condições gerais de vida da população brasileira. Que ao tratar da saúde se atreveram a discutir questões que, ao mesmo tempo, a transbordavam e a atravessavam. Eassim colaboraram decisivamente para um rico e complexo processo que acabaria por instituir, em âmbito constitucional, uma agenda social, baseada no direito e levada adiante por políticas descentralizadas e participativas.

Somente em parte a utopia se realizou. Resta, em boa medida, fazer valer por completo o que foi definido em texto constitucional. É evidente que os desafios, agora como antes, são imensos, e o caminho que obrigatoriamente se apresenta é de fortalecimento e radicalização das propostas definidas nos primórdios portantos abrasquianos. Mais do quetentar reviveruma utopia já vivida, é preciso reatualizá-la em termos que possa fazer sentido às novas gerações. Afinal, paixões se renovam! 
Sem perder de vista tantos corações e mentes apaixonados, nossa seleção de imagens reúnedocumentos, fotografias depersonagensemomentos decisivos, materiais de divulgação da associação, entre outros produtos que dão um pouco a medida de uma instituição que alcança os seus 35 anos de idade. Ao mesmo tempo madura e repleta de desejos e sonhos, típicos da juventude.

Procurou-se retratar a trajetória da Abrasco por intermédio de seus encontros e congressos mais expressivos, suas comissões e reuniões mais relevantes ou fundantes de subáreas de conhecimento ou trabalho. Como o diálogo da associação com a sociedade sempre foi muitíssimo intenso, não deixamos de retratar alguns eventos em relação aos quais a ação da Abrasco tem sido, de alguma forma, digna de nota. Este é o caso, por exemplo, dos trabalhos de diversos membros da associação naquela que ainda é vista como a mais importante Conferência Nacional de Saúde, a $8^{\text {a }}$ CNS.

Mapear em imagens ou palavras uma trajetória tão rica e duradoura como a da Abrasco sempre será uma iniciativa condenada à incompletude e parcialidade. As tarefas de levantamento de fontes e identificação de personagens se mostraram um enorme desafio ao qual nos empenhamos em responder, mas só conseguimos fazê-lo parcialmente, mesmo contando com o apoio de fundadores da associação. Esperamos, contudo, que nossa contribuição possa representar um passo repleto de significados e emoções para os que participaram desse empreendimento, de inspiração para os que a ele ainda se juntarão.

Carlos Henrique Assunção Paiva Vanessa Nolasco Ferreira 
Aos vinte e sete dias do mês de setembro de hum mil novecentos e setenta e nove, durante a I Reuniäo sobre Formação e Utilizaçäo de Pessoal de Níve1 Superior na Ärea da Saúde Coletiva, reuniram-se na sede da Organi zação Panamericana da Saủde, Organização Mundial da Saúde, em Brasília-DF, têcnicos, profissionais, alunos e professores da ärea de Saüde Coletiva com - objetivo de fundar una associaçāo que congregasse os interesses dos dife rentes cursos de pós-graduação naquela ärea. A reunião iniciou-se soba dí reção do Doutor Carlyle Guerra de Macêdo e os presentes concordaram unanī mimente com a fundaçăo de uma associação com as características acima meñ cionadas. Logo em seguida foi aprovada, por unanimidade, a constituiçäo dē uma diretoria provisória que deverả reger os destinos da nova associação atê sua constituição definitiva com a aprovaçăo e legalizaçäo de seus esta tutos. Foram eleitos: Frederico Adolfo Simoes Barbosa Presidente, e Erna ni de Paiva Ferreira Braga e Guilherme Rodrigues da Silva Vice-Presideñ tes. Ficou decidido ainda que o Presidente indicaria um SecretärioExecutî vo como membro da Diretoria provisória. Em seguida o Presidente eleito, a companhado dos Vice-presidentes, assumiu a coordenação da reunião. Ficoū aprovado que a nova associação seria denominada ASSOCCIAÇAO BRASILEIRA DE PÖS-GRADUAÇAO EM SAODE COLETIVA, com sede e foro em Brasília, Distrito Fe deral. As seguintes decisões foram ainda aprovadas pelo plenärio: $1 . t o d o \bar{s}$

- os que assinaram a ata de presença desta reunião seráo considerados sốcios fundadores individuais; 2 . a Associação, alêm dos sôcios individuais, deve rá tambêm ter em seus quadros sôcios institucionais, alẻm de outras possí veis categorias. 0 prazo para o mandato da presente Dìretoria näo foì fí xado, tendo-se entretanto, recomendado gue este prazo fosse o menor poss $\underline{1}$ vel, embora o suficiente para permitir a Diretoria concluir as atividades previstas para consolidaçăo da nova associação. Foi decidido que após este período o Presidente deverả convocar uma reunião da Assemblé̉ia Gera1 na qual: 1. A Diretoria deverá prestar contas das atividades exercidas dú rante sua gestão; 2. deveräo ser aprovados os Estatutos da Associação $\bar{e}$ realizada a eleição e posse da nova Diretoria de acordo com o estabelecí do nos Estatutos. Finalmente, os presentes endossaram, por unanimidade, as conclusões da "I Reunião sobre Formação e Utîlizaçäo de Pessoal de Ni vel Superior na Area da Saüde Coletiva" e, tambẻm, por unanimidade, e $5 \circ \bar{b}$ aplausos, aprovaram uma moção de reconhecimento e gratidão ao Doutor Car lyle Guerra de Macêdo pelo êxito da reunião. Nada mais havendo a trata $\bar{r}$, foi lavrada a presente ata de fundação da ASSOCIAÇ尺̃o BRASILEIRA DE POSGRADUAÇAO EM SAƯDE COLETIVA que é assinada pelo seu Presidente recém-ele to e pelo Presidente "ad hoc" desta reunião, Brasilia vinte e sete de setembro de hum mil e novecentes e setenta e nove.

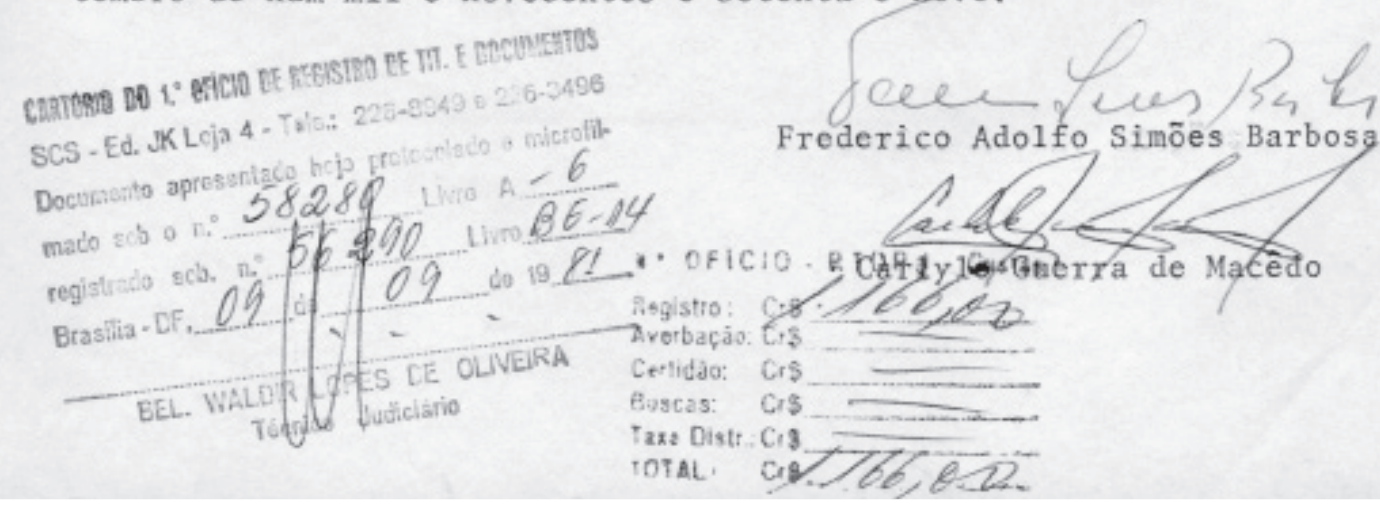

Ata de fundação da Abrasco. Brasília, 27 de setembro de 1979. Acervo Abrasco. 


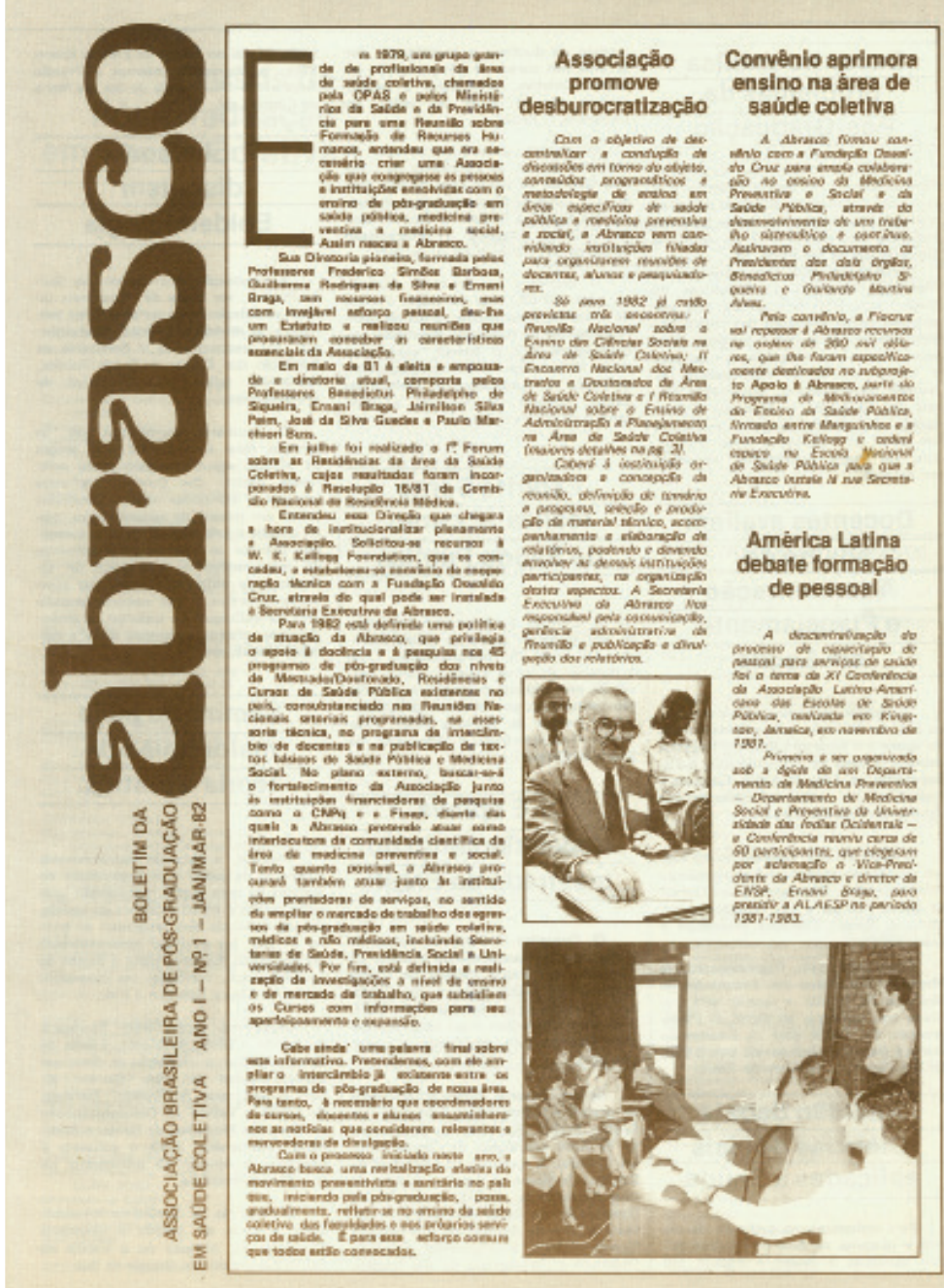

Primeiro Boletim Abrasco, jan./mar. 1982.

Acervo Abrasco.

Charge alusiva ao momento político em que a Abrasco é criada. "Quebra-nós".

Autor: Mayrink. Boletim Abrasco, n. 13, nov./dez. 1984. Acervo Abrasco.

\section{ENQUANTO ISSO...}

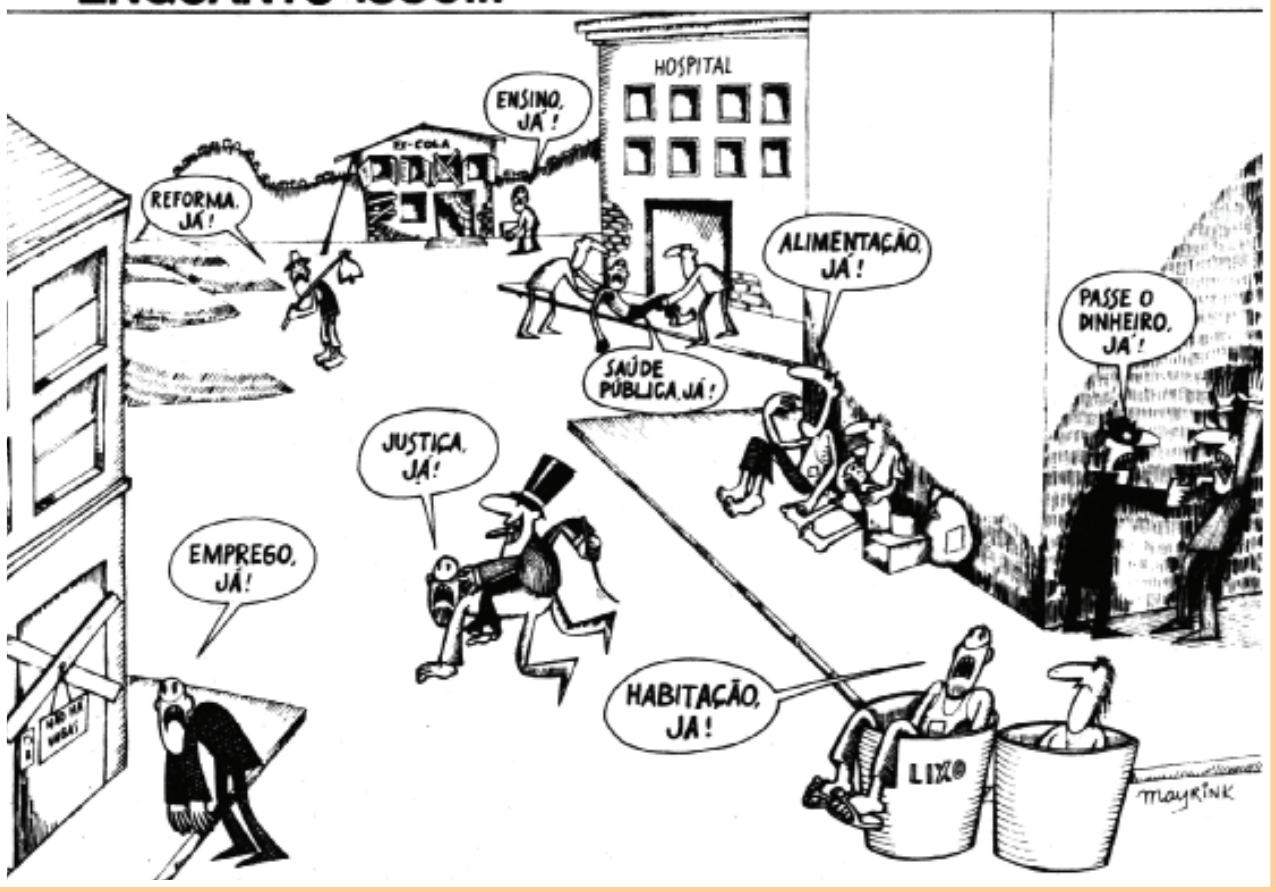




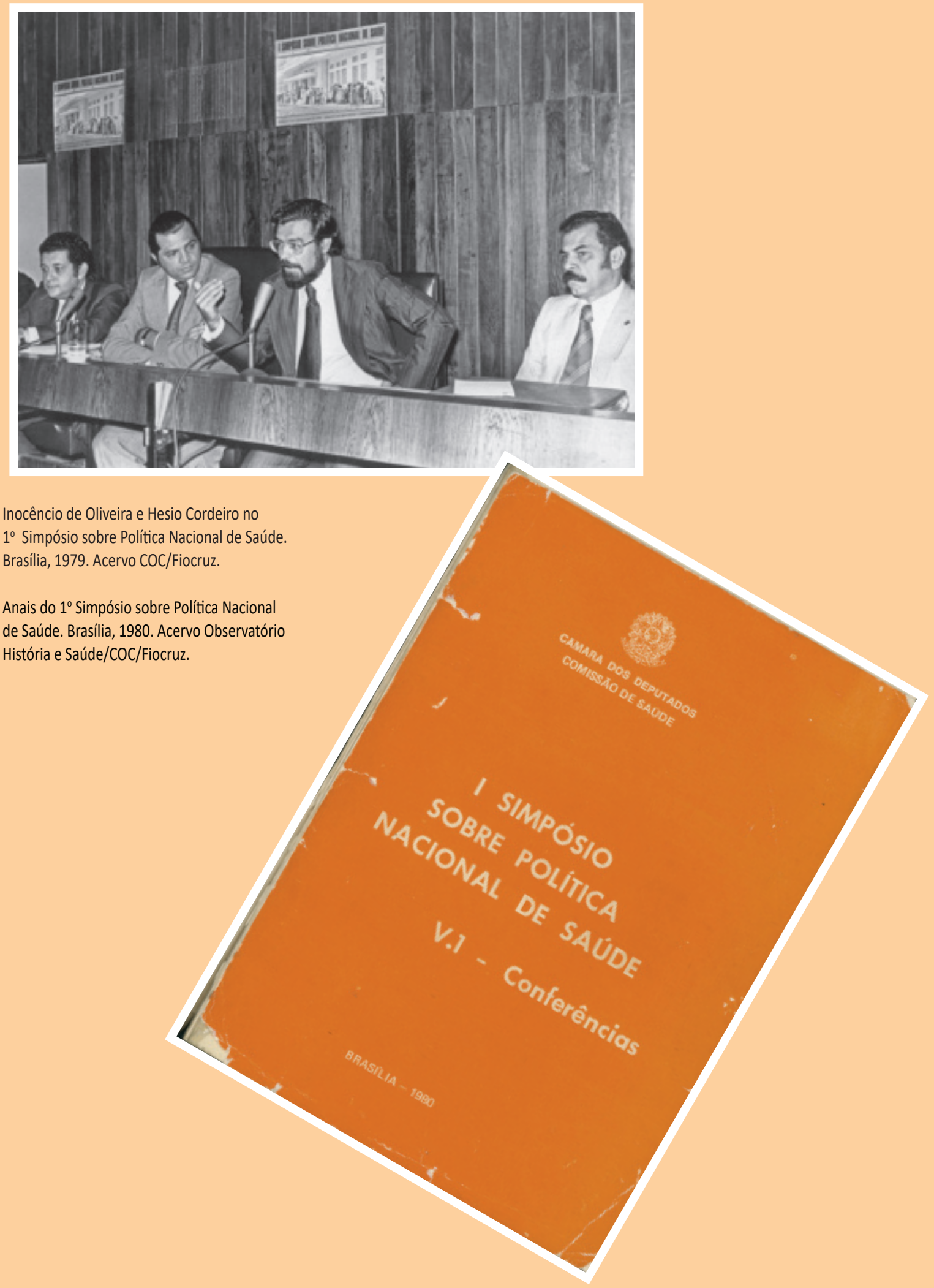




\section{abrasco}

Associaçào Brasileira de Pós-Graduação em Saúde Coletiva

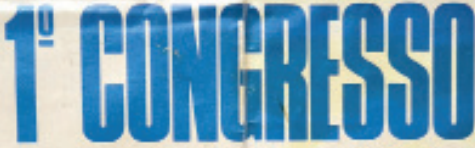
Bin

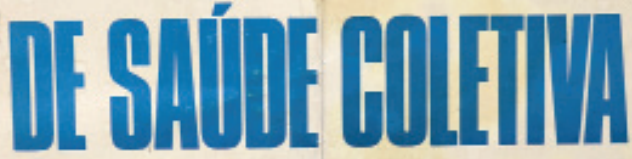

REFORMA SANITÁRIA E CONSTITUINTE Garantia do Direito Unlversal à Saúde

Cartaz do $1^{\circ}$ Congresso Brasileiro de Saúde Coletiva. Rio de Janeiro, setembro de 1986. Acervo Abrasco.

Edição especial do Boletim Abrasco, n. 19, jul./set. $1986-1^{\circ}$ Congresso Brasileiro de Saúde Coletiva. Acervo Abrasco.

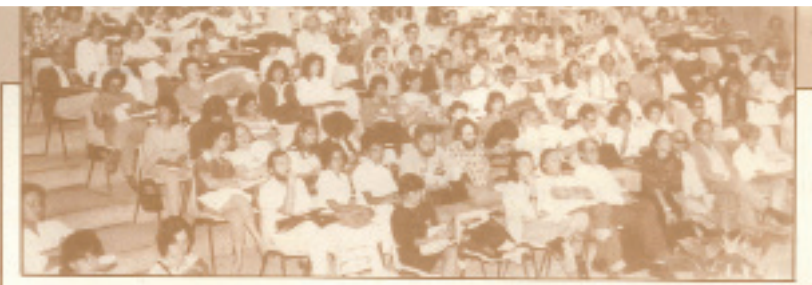

Declaração final do 1 ? Congresso Brasileiro de Saúde Coletiva

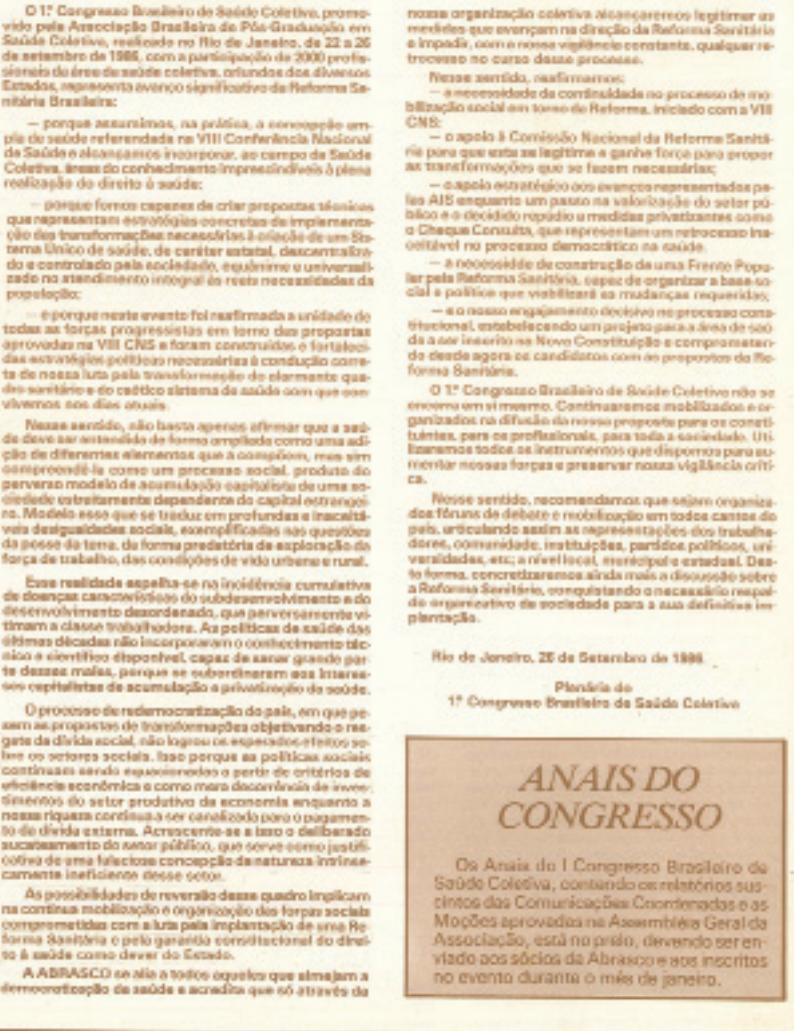




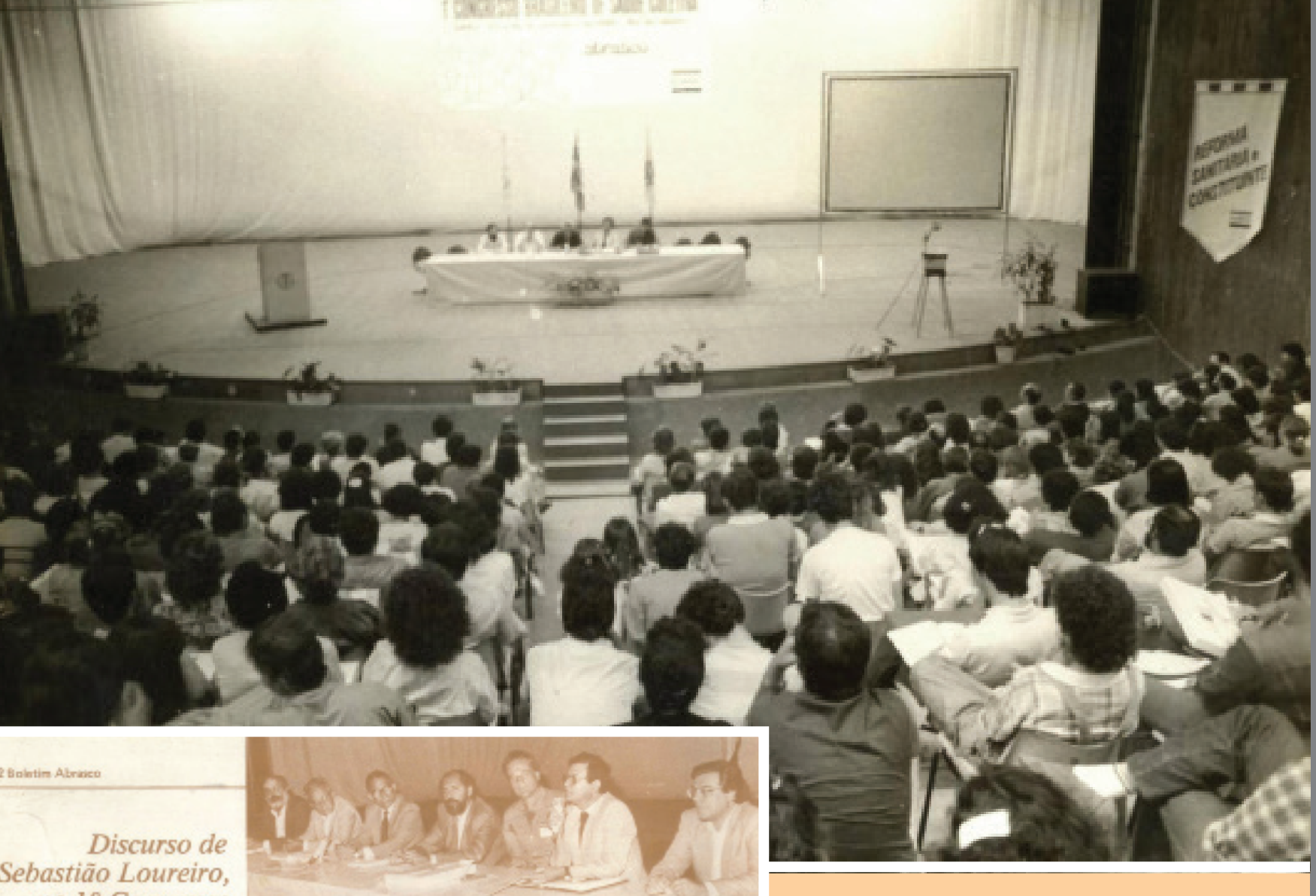
no $1 .{ }^{\circ}$ Congresso

Brasileiro de Saúde Coletiva

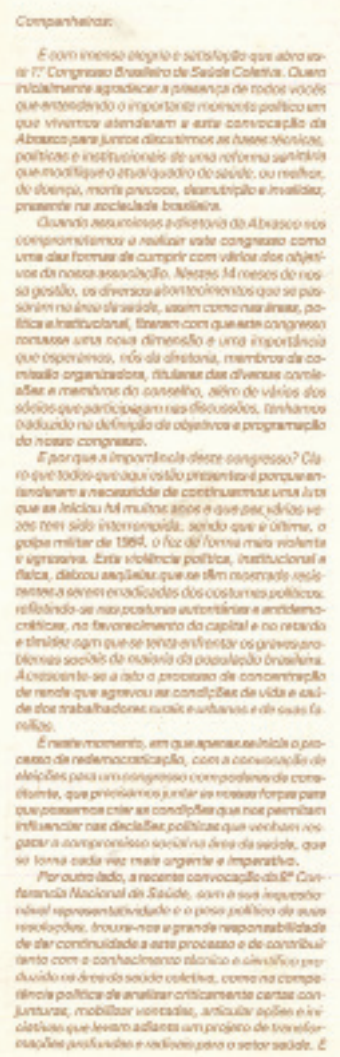

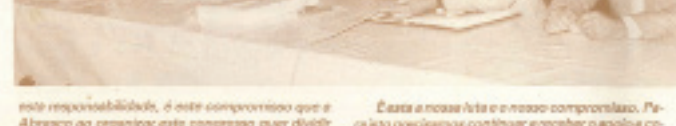

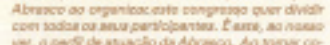

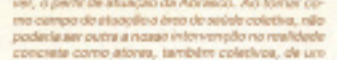

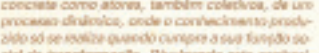

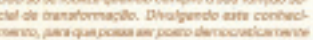

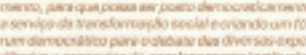

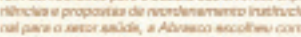

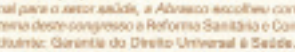

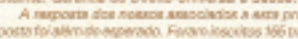

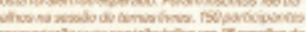

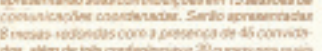

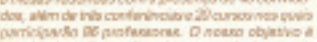

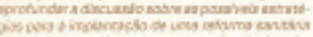

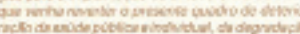

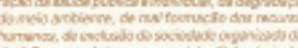

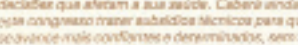

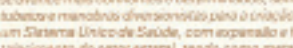

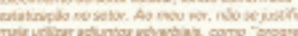

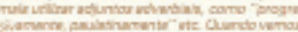
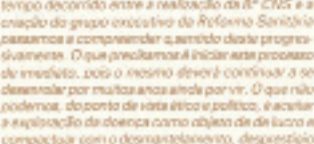

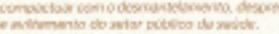

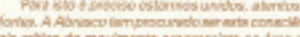

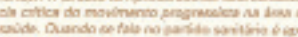

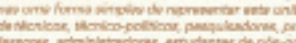

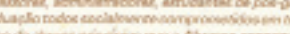

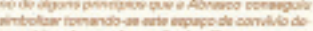

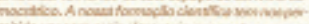

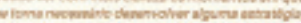

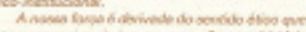

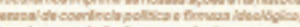
ster

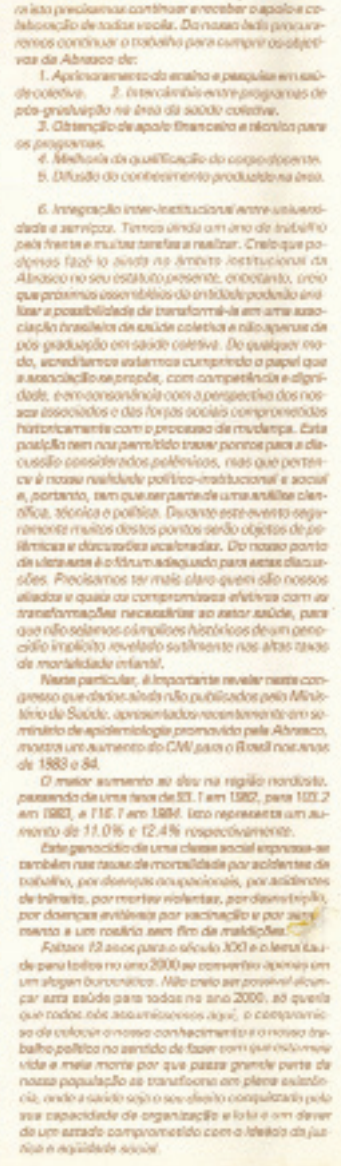

Abertura do $1^{\circ}$ Congresso Brasileiro de Saúde Coletiva. Universidade do Estado do Rio de Janeiro, 22 de setembro de 1986. Acervo Radis/Ensp.

Discurso de Sebastião Loureiro no $1^{\circ}$ Congresso Brasileiro de Saúde Coletiva. Boletim Abrasco, n. 19, jul./set. 1986. Acervo Abrasco. 

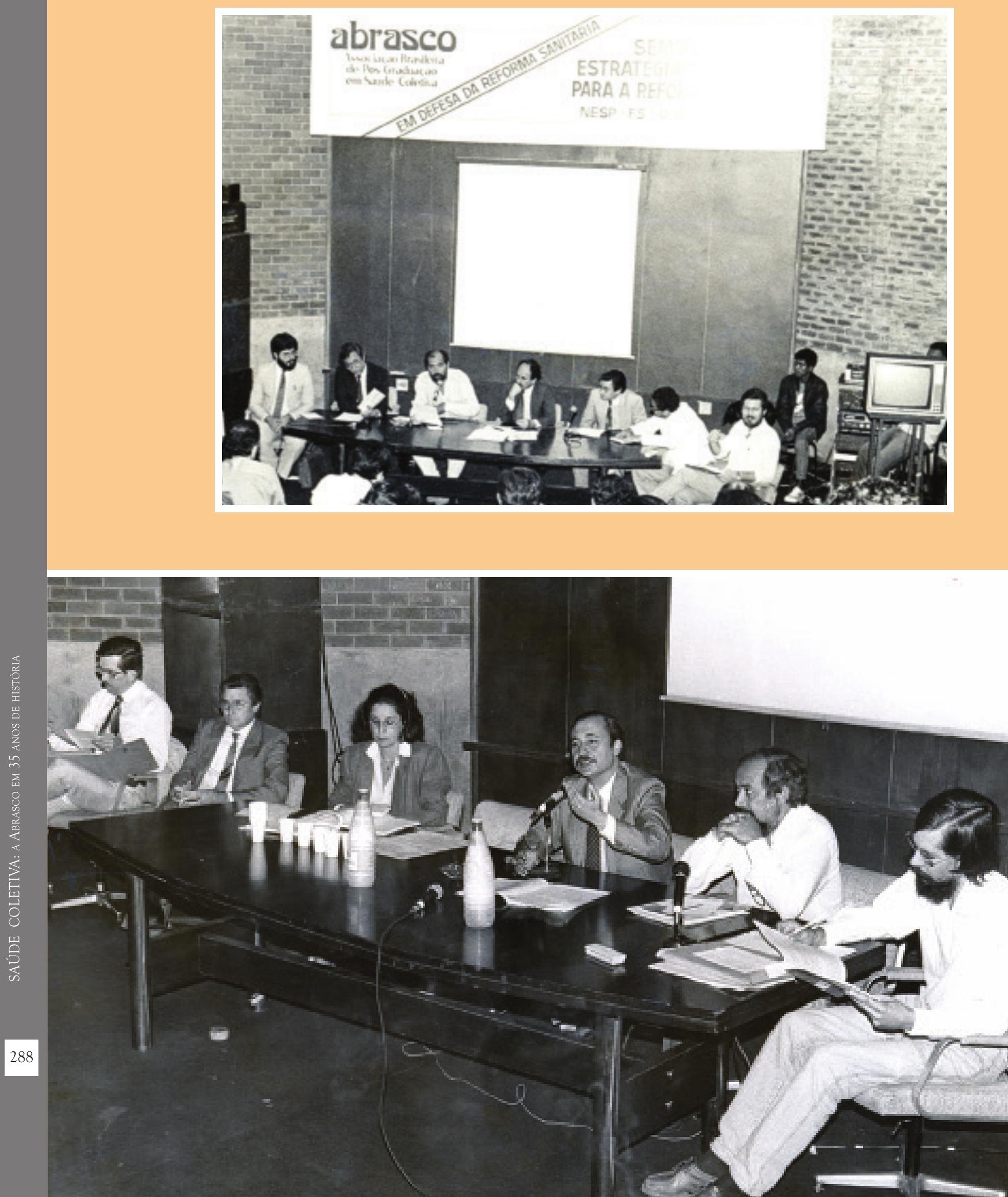


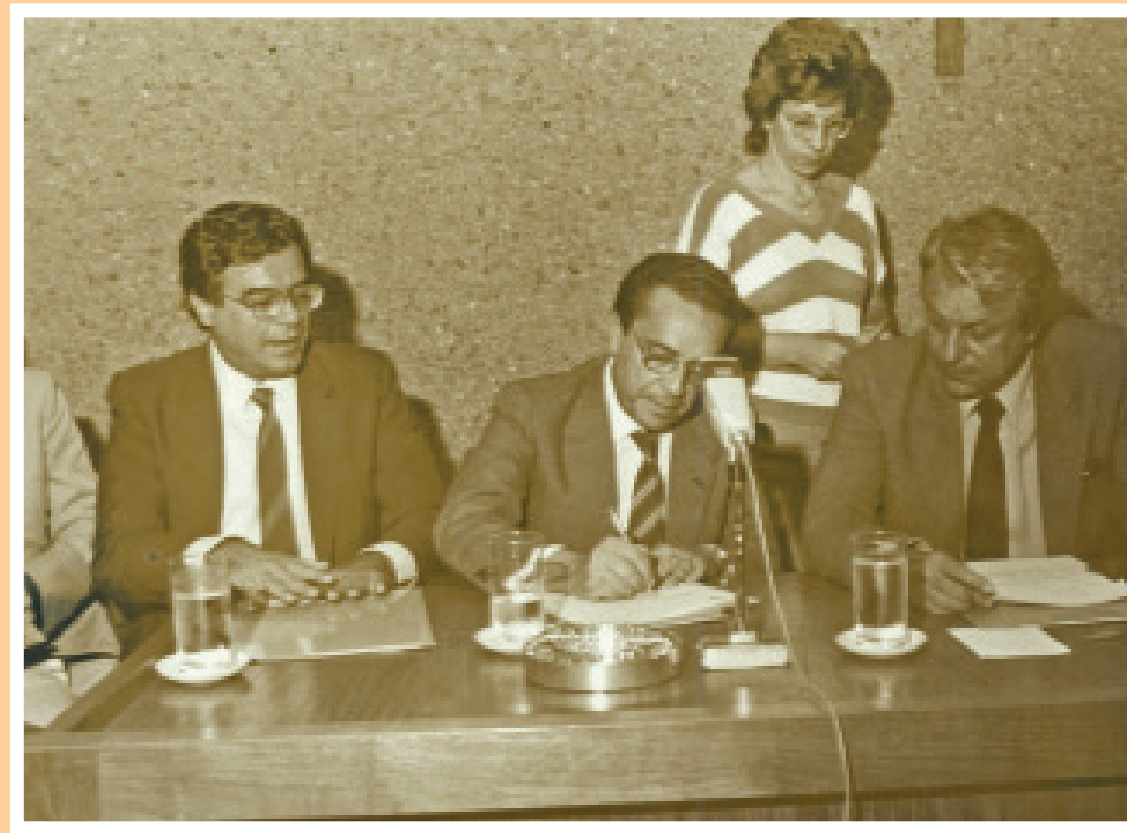

Hesio Cordeiro, Luiz Carlos Borges da Silveira, Raphael de Almeida Magalhães na ocasião da assinatura do convênio conhecido como Sistema Unificado Descentralizado de Saúde (Suds) entre Inamps e governos estaduais, 1987. Acervo COC/Fiocruz.

Boletim Abrasco, n. 19, jul./set. 1986.

Acervo Abrasco.
Charge alusiva à insuficiência do salário mínimo. Autor: Mayrink. Boletim Abrasco, n. 18, abr./jun. 1986. Acervo Abrasco.
Abrasco propōe texto sobre saúde para a constituinte

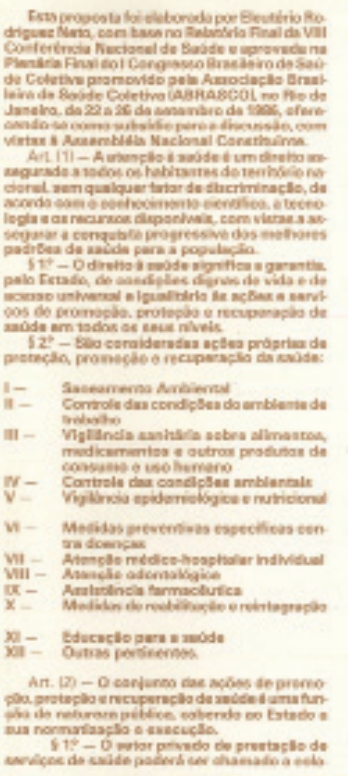

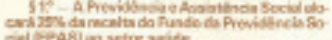

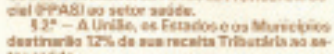

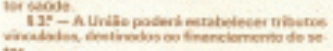

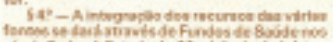

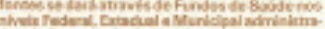

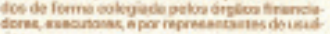

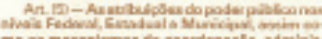

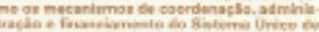

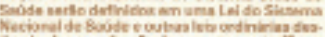

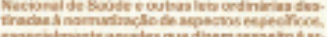

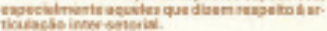

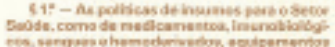

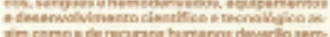

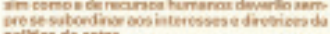

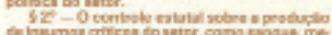

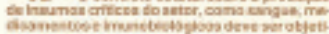

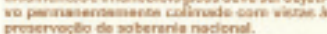
Ant. IE - A Patrica Macional de Sacido co

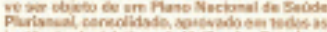

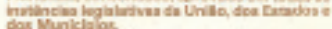

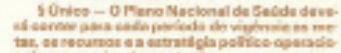

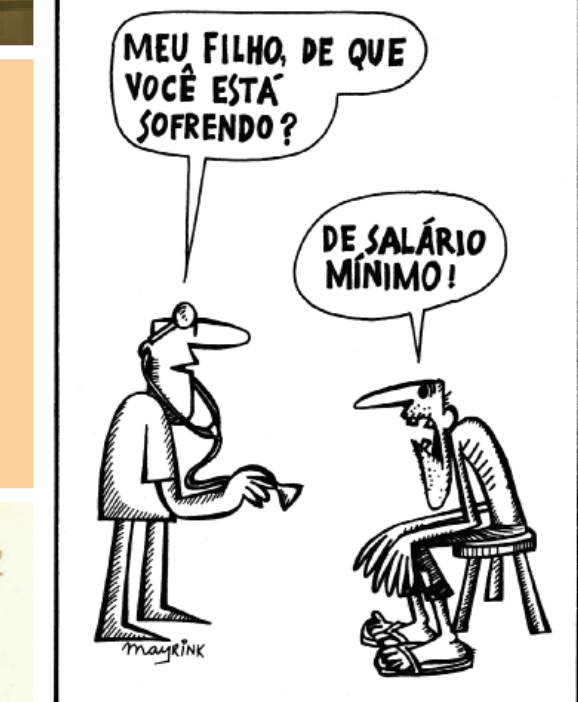

MEU FILHO, DE QUE VOCE ESTA SOFRENDO? 


\section{A A A construnte dos avanços}

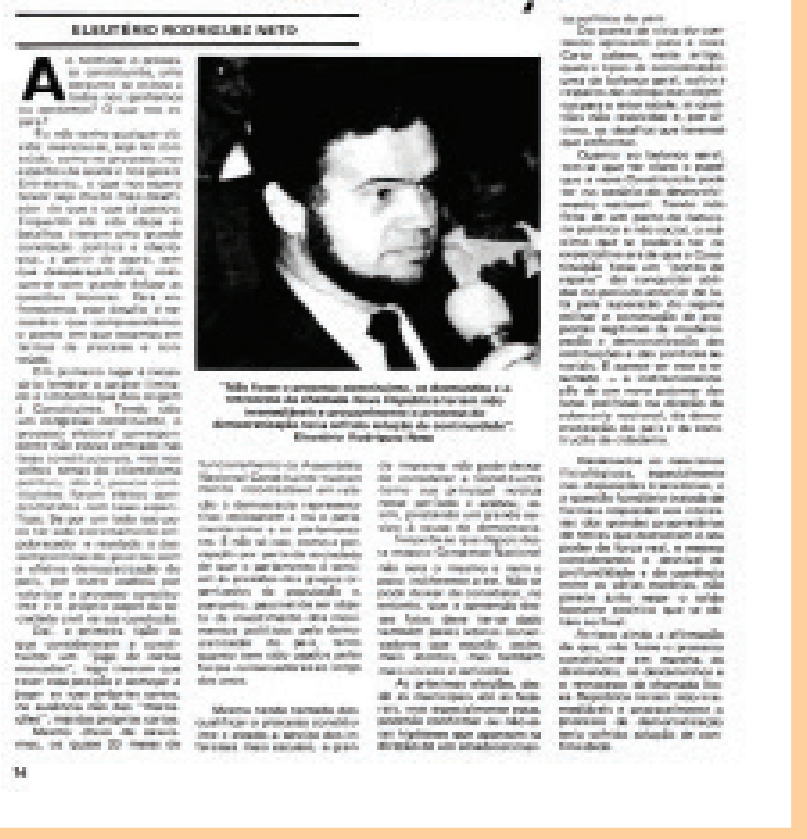

Entrevista com Eleutério Rodriguez Neto. Revista Tema, n. 11, 14 nov.1988, p. 14. In: Coletânea Radis 20 Anos. 3. ed. Rio de Janeiro: Programa Radis/Ensp, 2010. CD-ROM.

Ulysses Guimarães, presidente da Assembleia Nacional Constituinte, segura exemplar da nova Constituição brasileira, 1988. Acervo Agência Brasil.

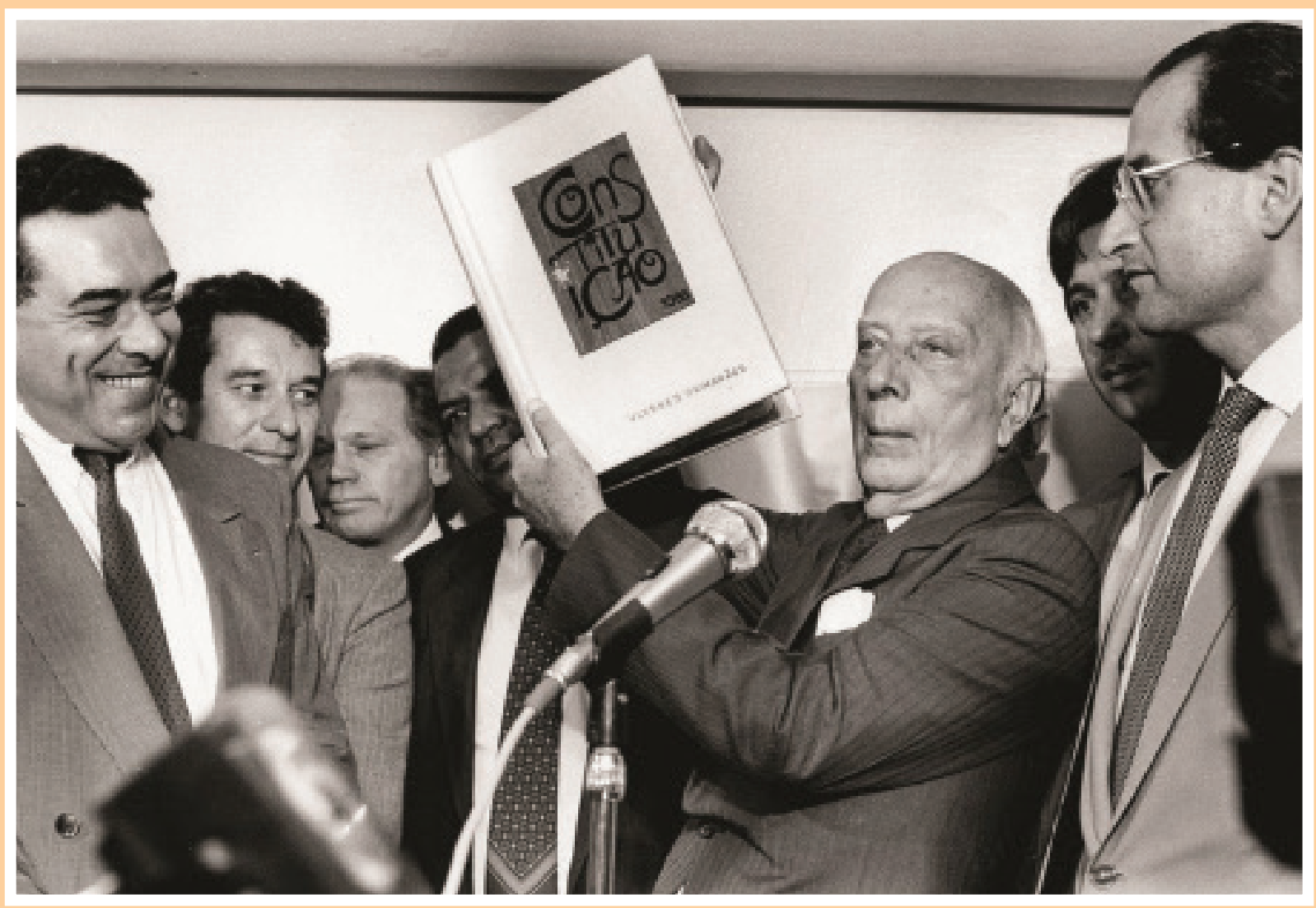


Eleutério Rodriguez Neto no $2^{\circ}$ Congresso Brasileiro de Saúde Coletiva. São Paulo, julho de 1989. Acervo Abrasco.

$2^{\circ}$ Congresso Brasileiro de Saúde Coletiva. São Paulo, julho de 1989. Da esquerda para direita: Eduardo Jorge, Seigo Tzusuki, Eleutério Rodriguez Neto, Pedro Dimitrov, Hugo Villegas e José Noronha. Acervo Abrasco.

Edição especial 10 anos do Boletim Abrasco, n. 34, jun./jul. 1989. Encarte do $2^{\circ}$ Congresso Brasileiro de Saúde Coletiva. Acervo Abrasco.
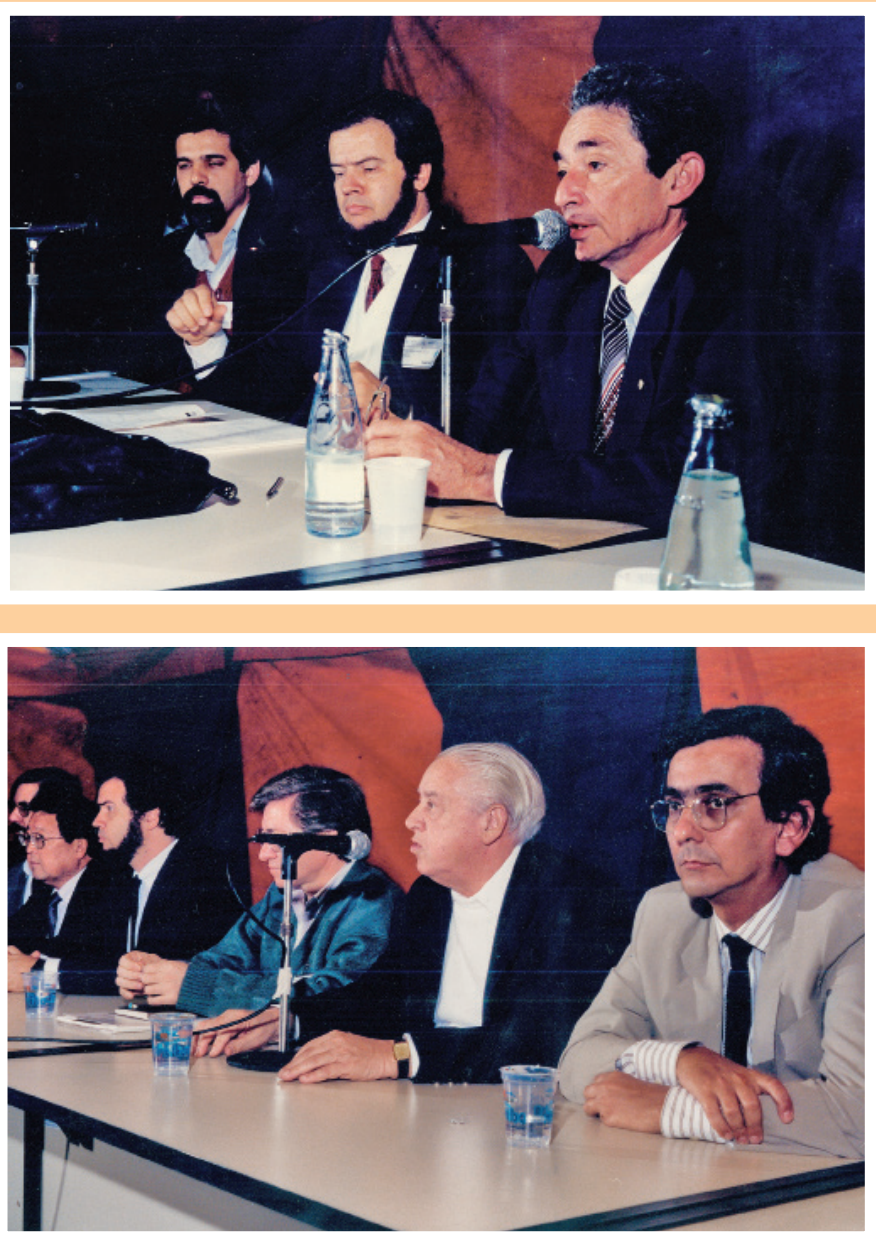

Cartaz do $2^{\circ}$ Congresso Brasileiro de Saúde Coletiva e $13^{\circ}$ Congresso Paulista de Saúde Pública. São Paulo, julho de 1989.

\section{$2^{11}$ CONGIRESSO} BRASHEIR() DDE SHOHCOLETIA

30 CONGRESSO PAULSPA DE SAUIDE PUBLLCA mava gaco oisates

Adib Jatene e Eleutério Rodriguez Neto no $2^{\circ}$ Congresso Brasileiro de Saúde Coletiva. São Paulo, julho de 1989. Acervo Abrasco. 


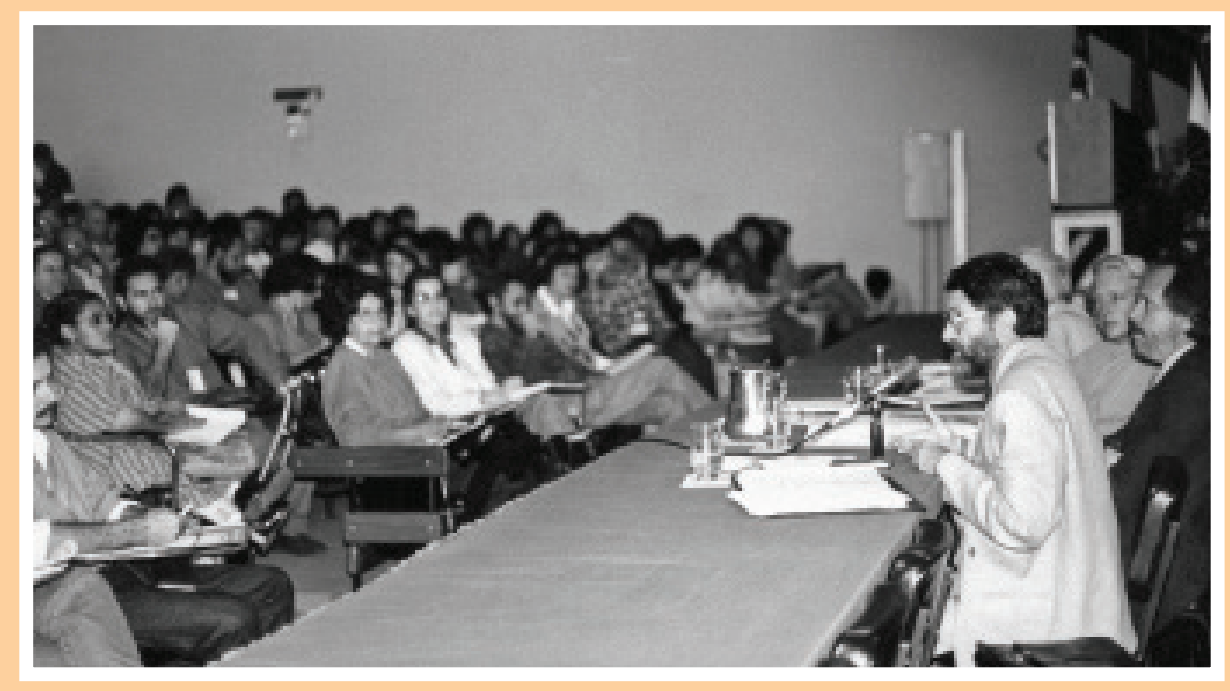

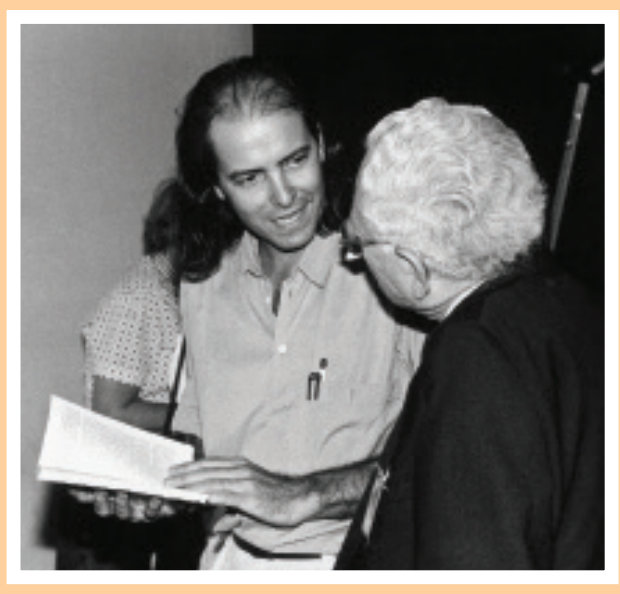

$1^{\circ}$ Congresso Brasileiro de Epidemiologia. Da esquerda para direita: Moisés Goldbaum, Reinaldo Guimarães, Asa Laurell e Milton Ferris. Campinas 2 a 6 de setembro de 1990. Acervo Abrasco.

$1^{\circ}$ Congresso Brasileiro de Epidemiologia. Da esquerda para direita: Naomar Almeida Filho e Frederico Simões Barbosa. Campinas 2 a 6 de setembro de 1990. Acervo Abrasco.

Edição especial do Boletim Abrasco, n. 40, set. 1990. Encarte do $1^{\circ}$ Congresso Brasileiro de Epidemiologia. Acervo Abrasco.

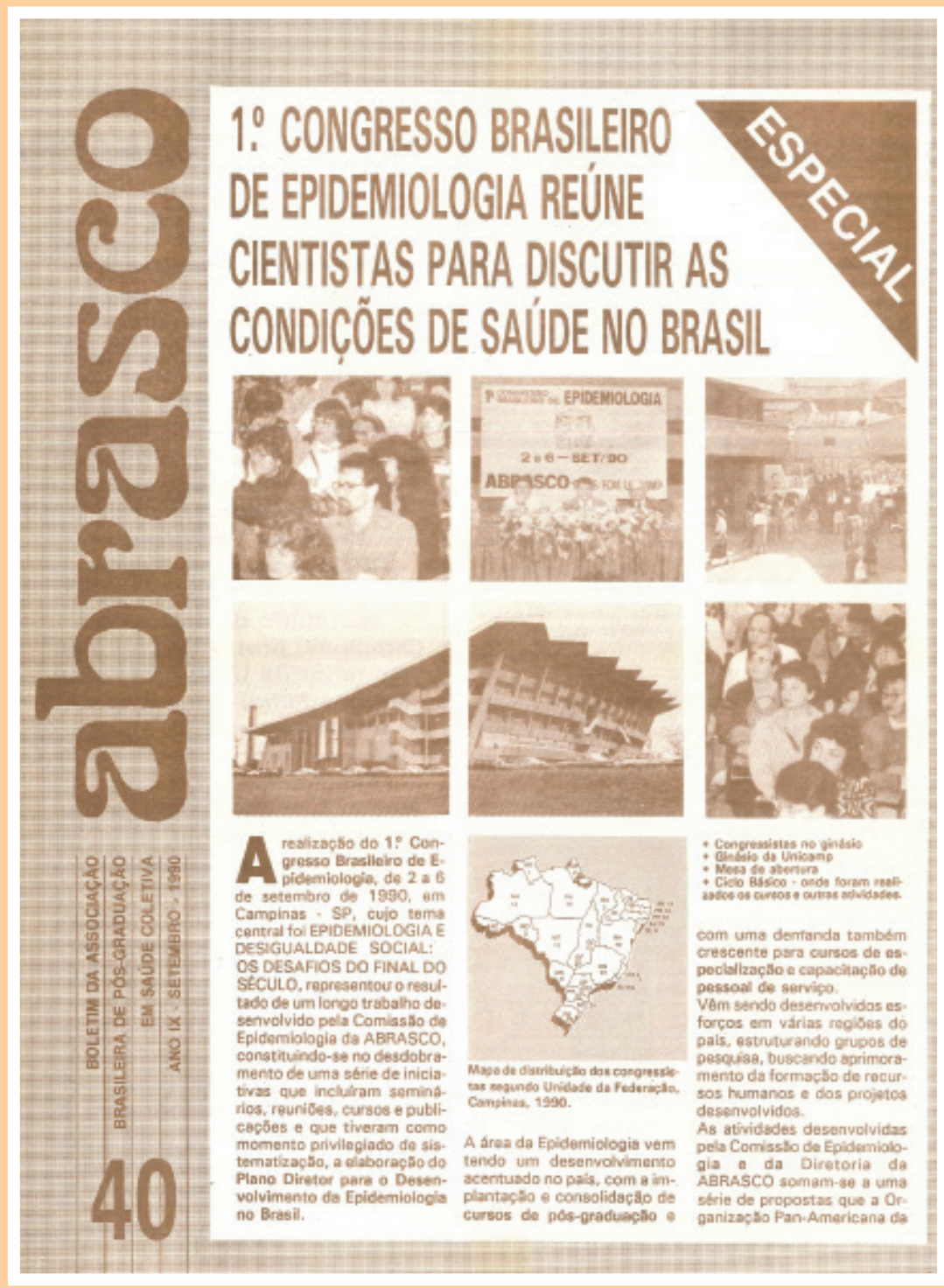




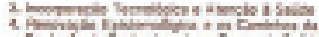

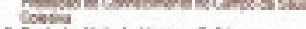

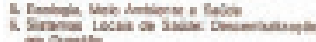

Comuleaptan Coencomatas

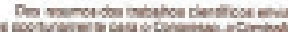

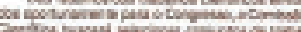

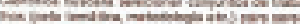

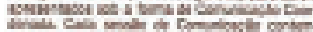

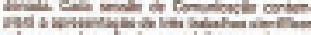

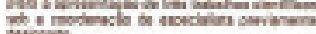
aiplace

Nowen

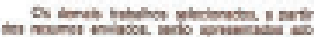

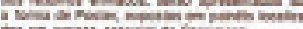

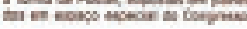

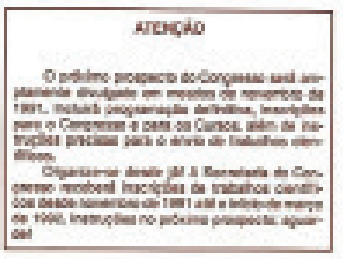

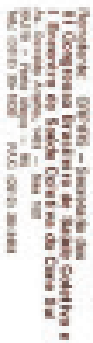

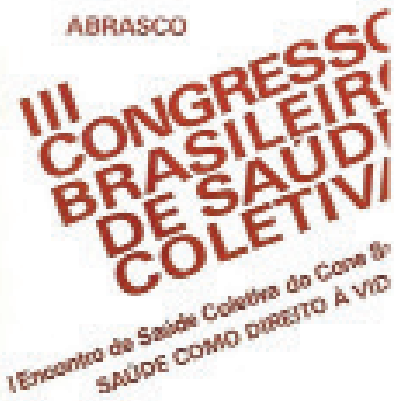

16 a 20 do maio de 199 ? Compus derense - Moro Alegers as

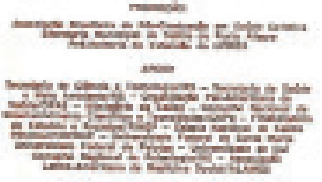

\section{INDIGNAÇÃO}
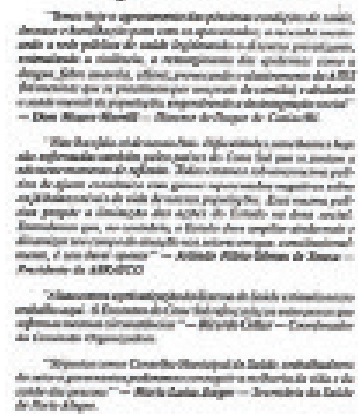

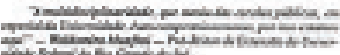

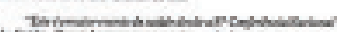

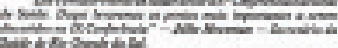
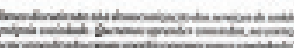

-

+

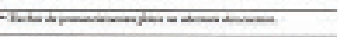

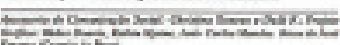

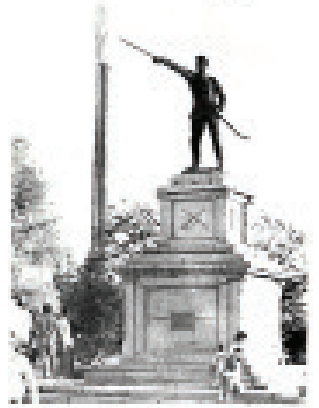

CARTA DE PORTO ALEGRE

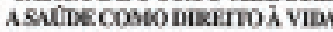

II CONGIRESXO HRASIILEIRO DE SIIDEE COLETIXE inscowing COL.TrVh DO CONE SLL FERA DESAOUEDE FOECTOALCGKE

Prospecto do $3^{\circ}$ Congresso Brasileiro de Saúde Coletiva. Porto Alegre, maio de 1992. Acervo Abrasco.

Carta de Porto Alegre: a saúde como direito à vida. $3^{\circ}$ Congresso Brasileiro de Saúde Coletiva e $1^{\circ}$ Encontro de Saúde Coletiva do Cone-Sul. Porto Alegre, 16 a 20 de maio de 1992. Acervo Abrasco. 


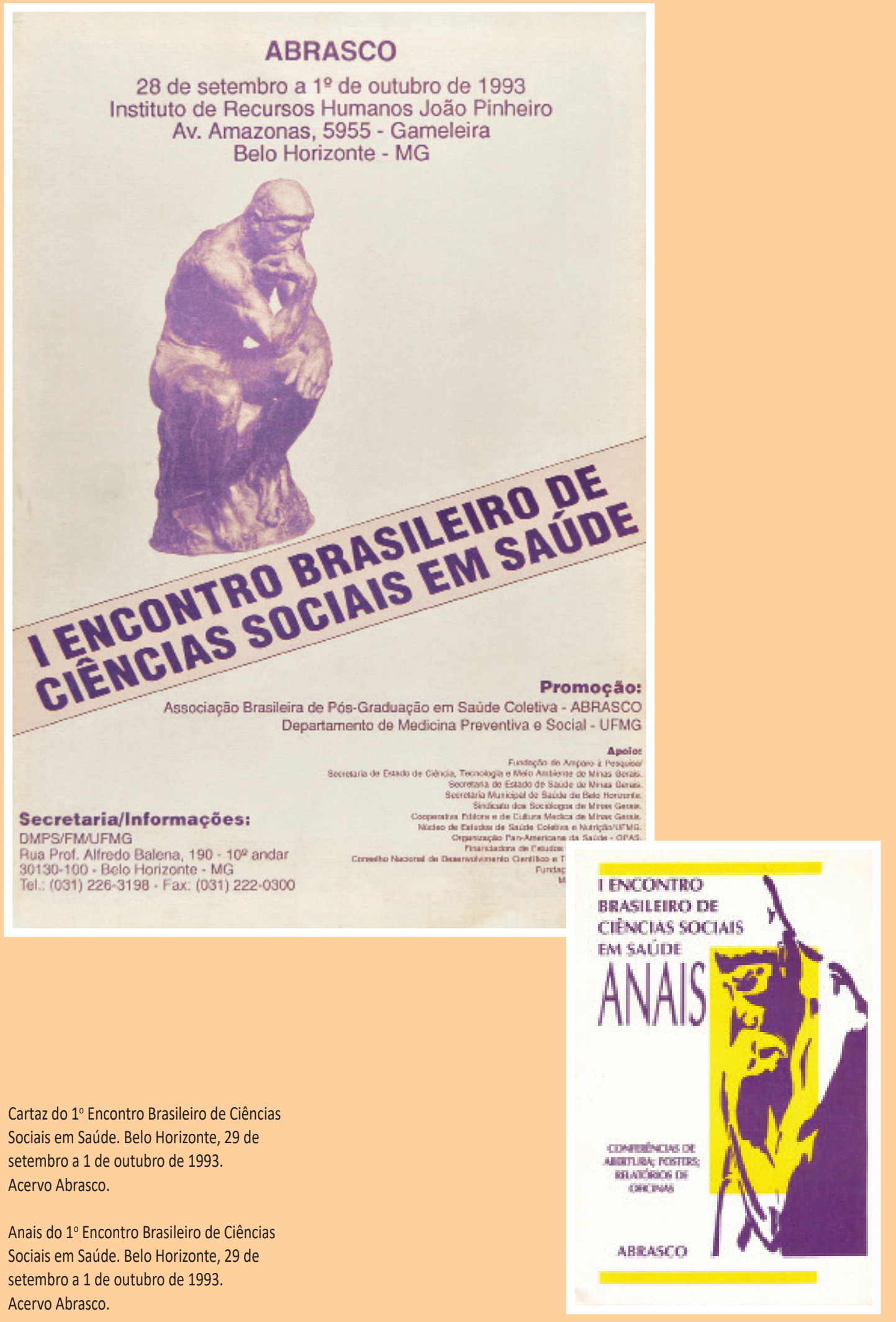



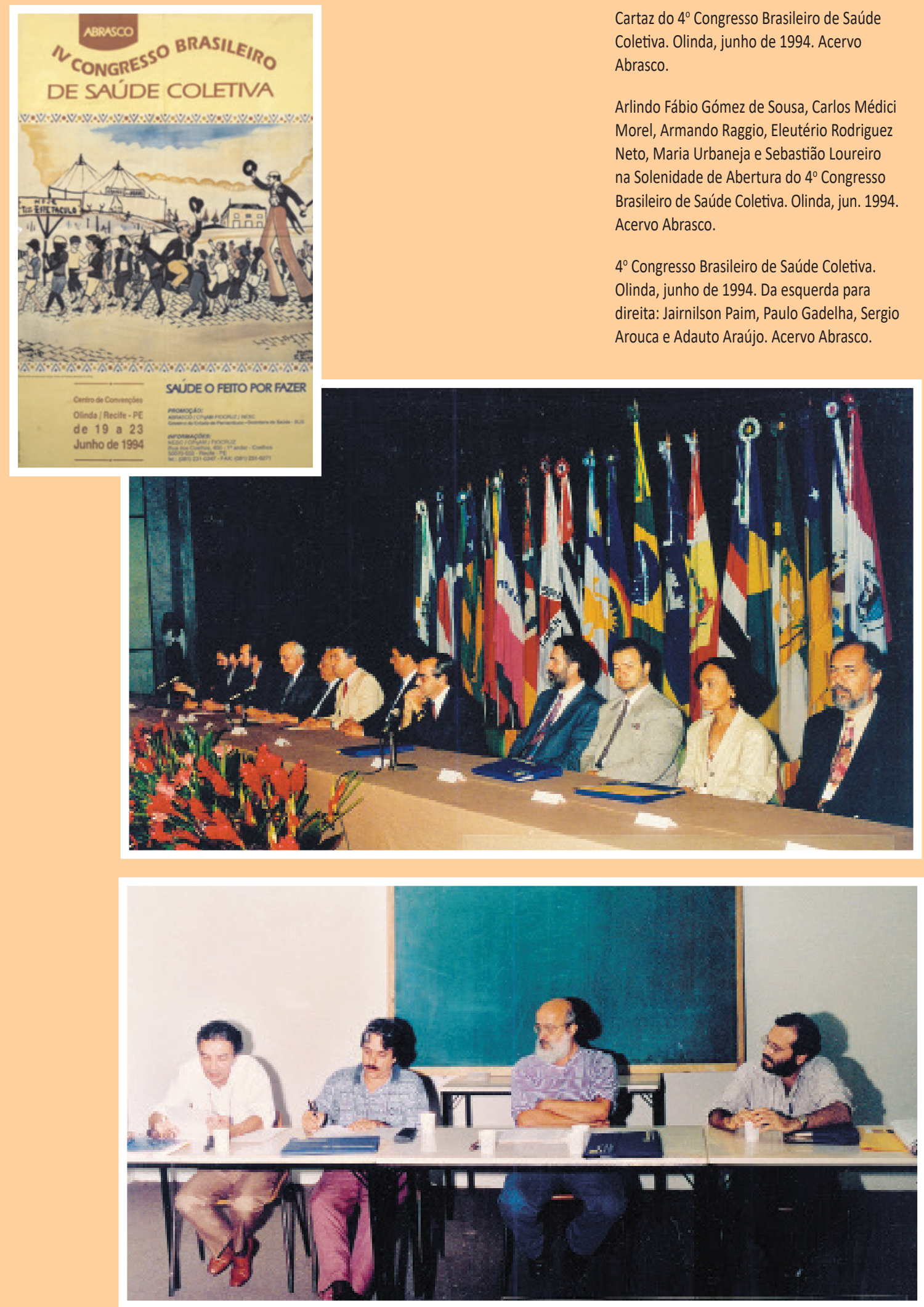


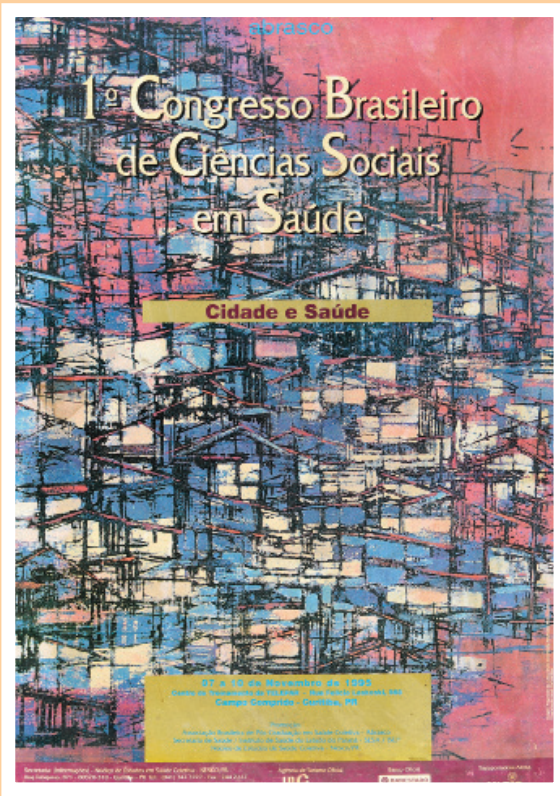

Cartaz do $1^{\circ}$ Congresso Brasileiro de Ciências Sociais em Saúde. Curitiba, 7 a 10 de novembro de 1995. Acervo Abrasco.

Primeiro número da revista Ciência \& Saúde Coletiva, 1996. Acervo Ciência \& Saúde Coletiva/Abrasco.

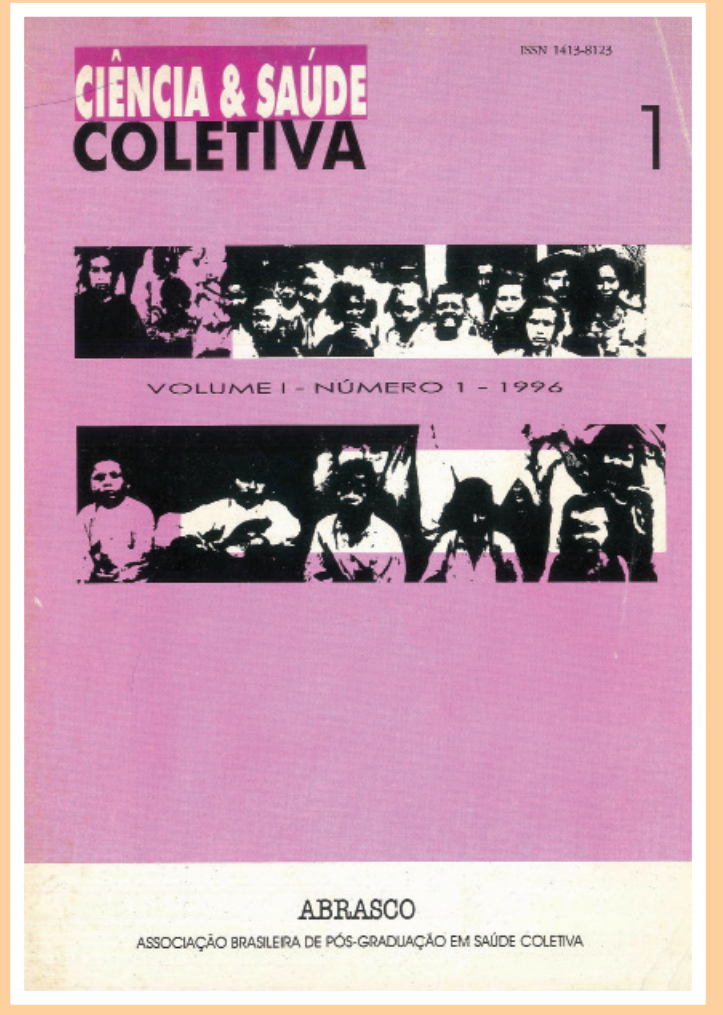

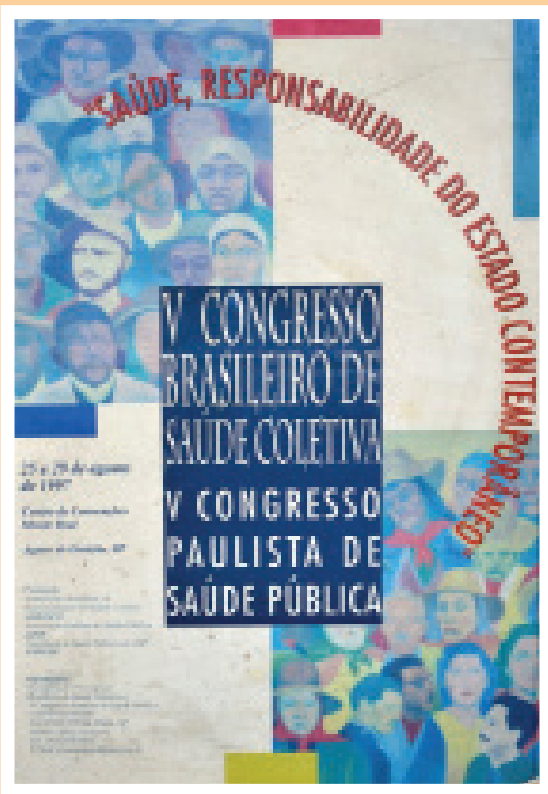

Cartaz do $5^{\circ}$ Congresso Brasileiro de Saúde Coletiva. Águas de Lindoia, 25 a 29 de agosto de 1997. Acervo Abrasco.

Primeiro número da Revista Brasileira de Epidemiologia, abr. 1998. Acervo Revista Brasileira de Epidemiologia/Abrasco.

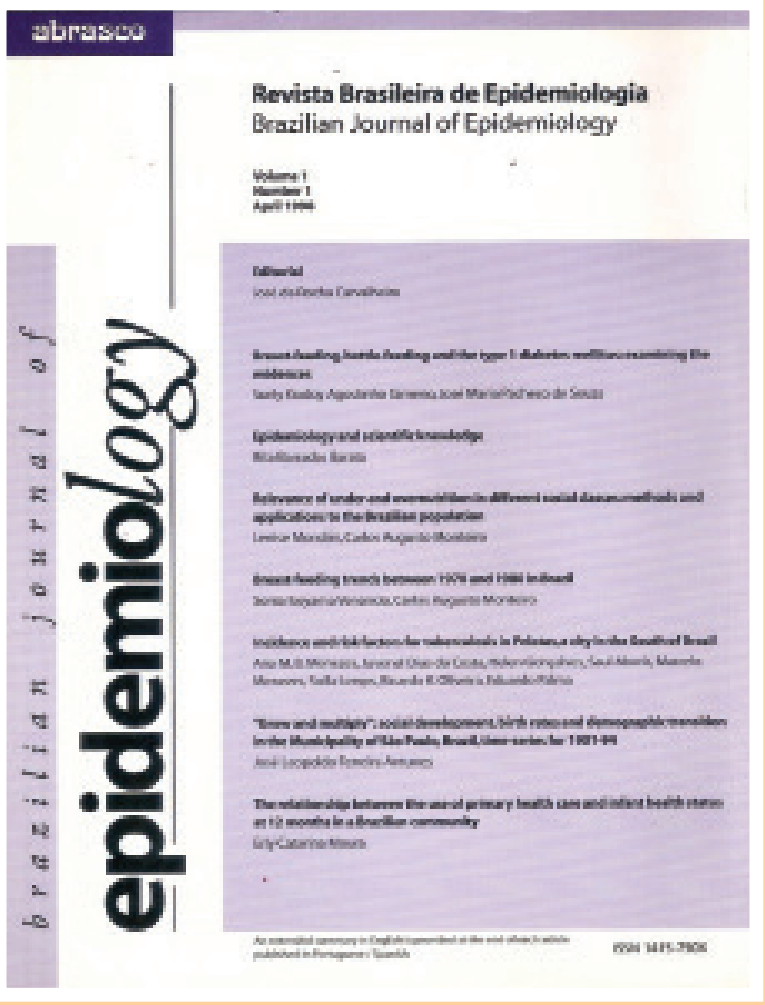




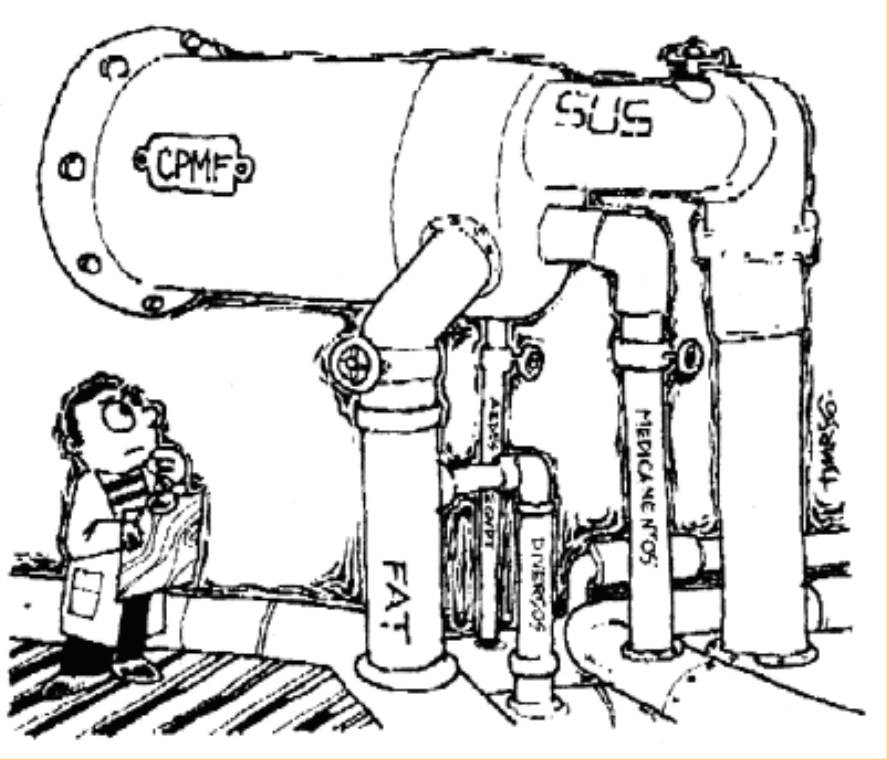

Charge relativa à criação da CPMF e ao

financiamento do setor Saúde.

Autor: Tibúrcio, Boletim Abrasco, 65,

abr./jun. 1997. Acervo Abrasco

Charge "O SUS no ano 2000". Autor: Tibúrcio,

Boletim Abrasco, n. 77, abr./jun. 2000.

Acervo Abrasco.

\section{O SUS no ano 2000:} Novos rumos, antigos (des)caminhos?

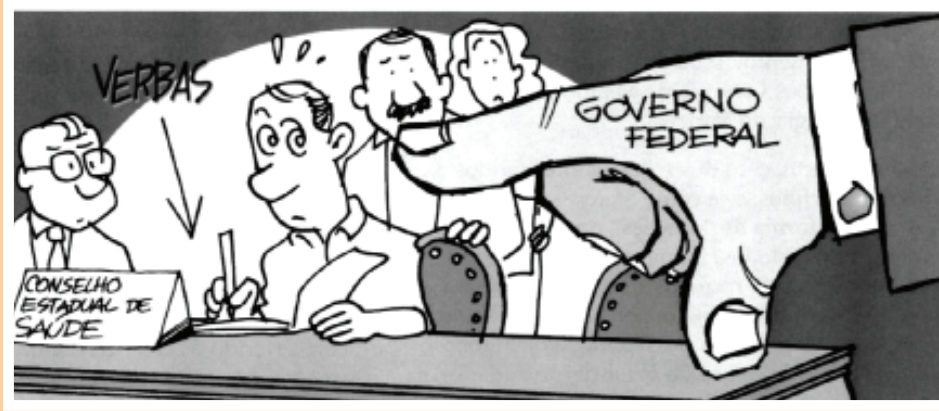

Cartaz do $6^{\circ}$ Congresso Brasileiro de Saúde

Coletiva. Salvador, 28 e agosto a

1 de setembro de 2000. Acervo Abrasco.

Madel T. Luz no $6^{\circ}$ Congresso Brasileiro de

Saúde Coletiva. Salvador, 28 de agosto a

1 de setembro de 2000. Acervo Abrasco.

Jairnilson Paim no $6^{\circ}$ Congresso Brasileiro de

Saúde Coletiva. Salvador, 28 de agosto a

1 de setembro de 2000. Acervo Abrasco.
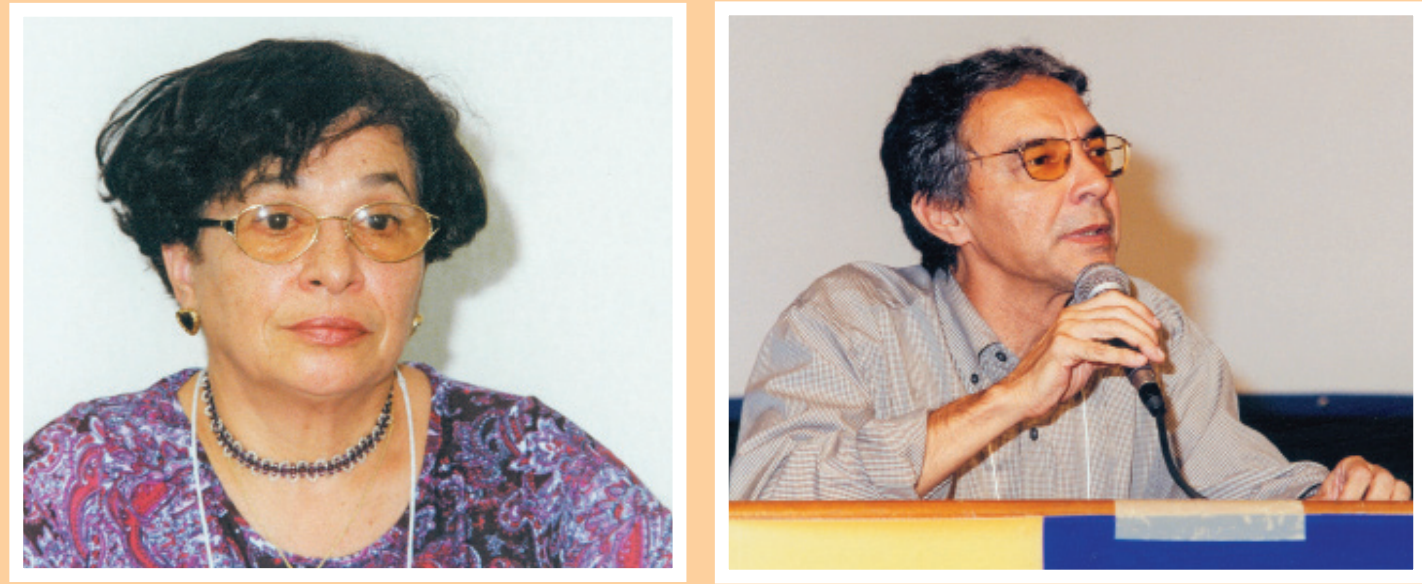


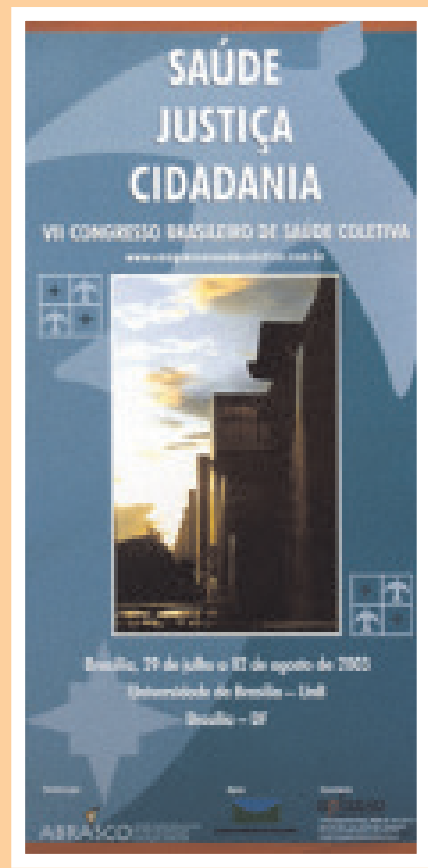

Cartaz do $7^{\circ}$ Congresso Brasileiro de Saúde Coletiva. Brasilia, 29 de julho a 2 de agosto de 2003. Acervo Abrasco.

José Noronha e Alvaro Matida no

$7^{\circ}$ Congresso Brasileiro de Saúde Coletiva. Brasília, 29 de julho a 2 de agosto de 2003. Acervo Abrasco.
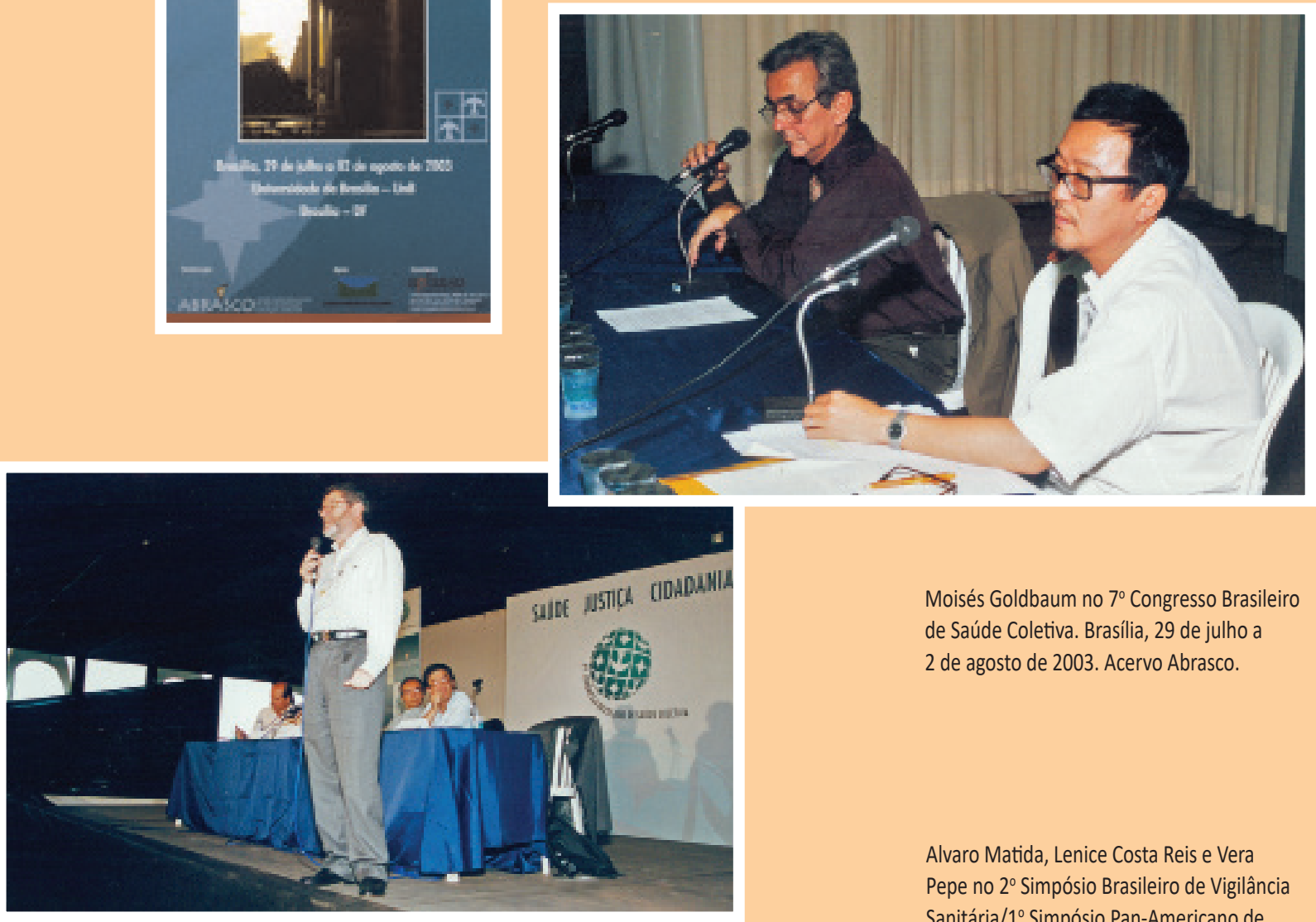

Moisés Goldbaum no $7^{\circ}$ Congresso Brasileiro de Saúde Coletiva. Brasília, 29 de julho a 2 de agosto de 2003. Acervo Abrasco.

Alvaro Matida, Lenice Costa Reis e Vera Pepe no $2^{\circ}$ Simpósio Brasileiro de Vigilância Sanitária/1 $1^{\circ}$ Simpósio Pan-Americano de Vigilância Sanitária. Caldas Novas, 21 a 24 de novembro de 2004. Acervo Abrasco.

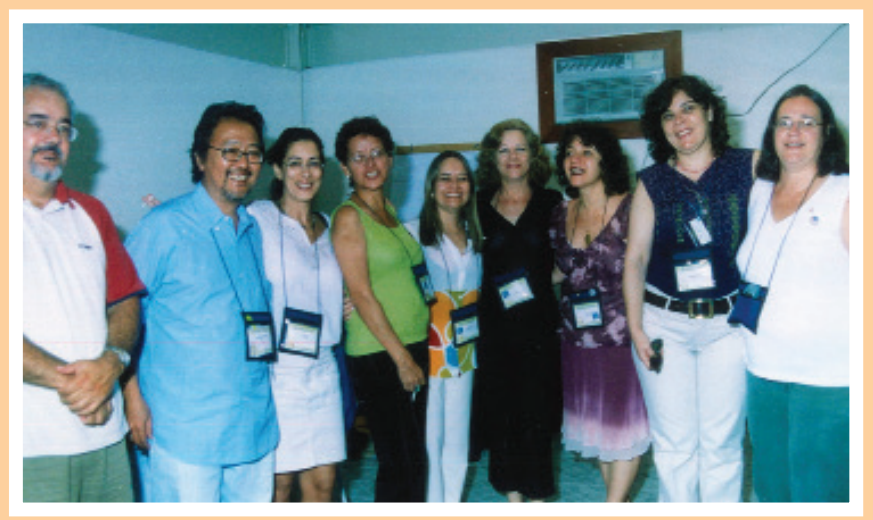




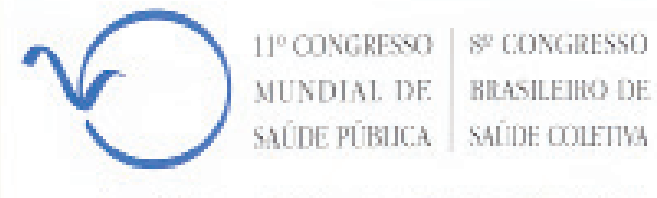

Rio de Juncios - Rressil - 21 a 25 de Agasto de 2016h

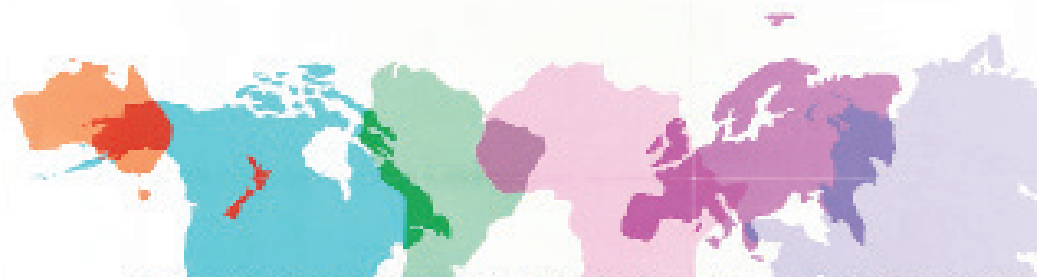

Saúde Coletiva em um mundo globalizado - Rompendo harreiras sociais, económicas e politicas

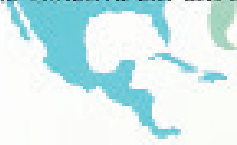

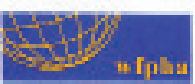

ABRASCO

Cartaz do $11^{\circ}$ Congresso Mundial de Saúde Pública $/ 8^{\circ}$ Congresso Brasileiro de Saúde Coletiva. Rio de Janeiro, agosto de 2006.

Boletim Abrasco, n. 97, out. 2006. Edição especial do $11^{\circ}$ Congresso Brasileiro de Saúde Coletiva $/ 8^{\circ}$ Congresso Mundial de Saúde Pública. Acervo Abrasco. AD B

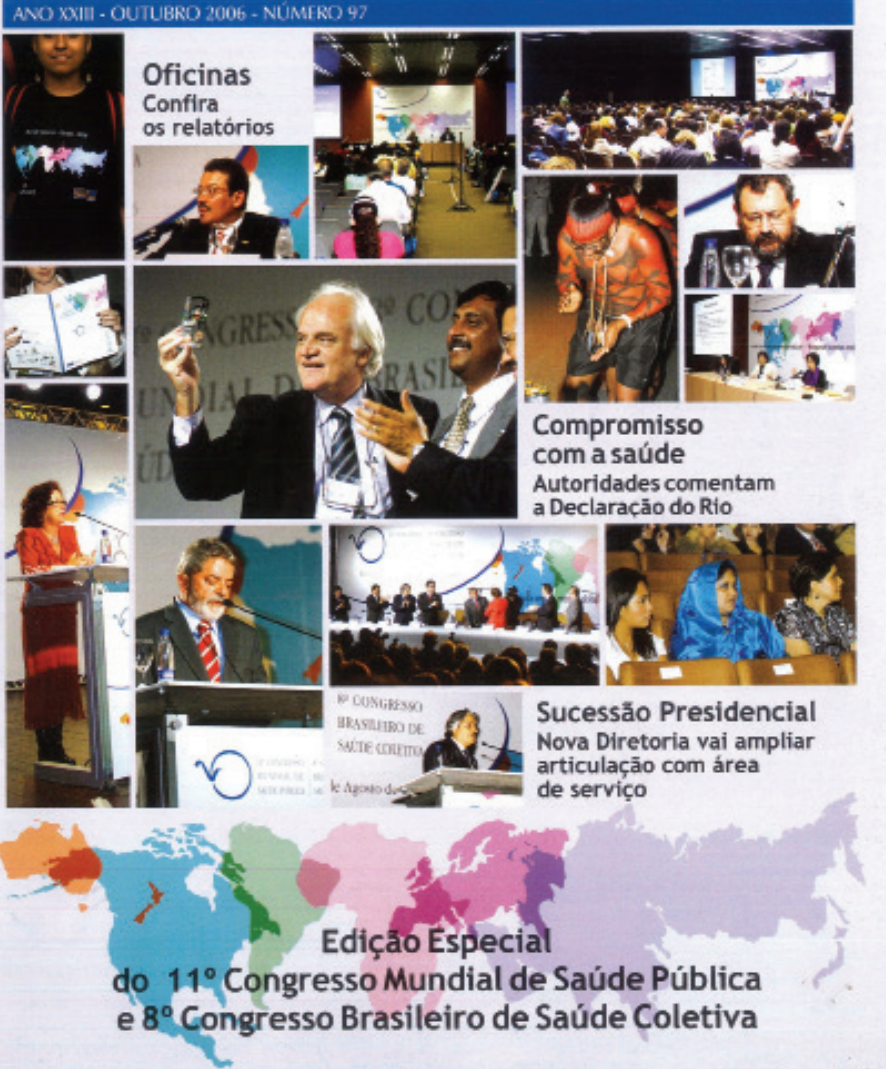




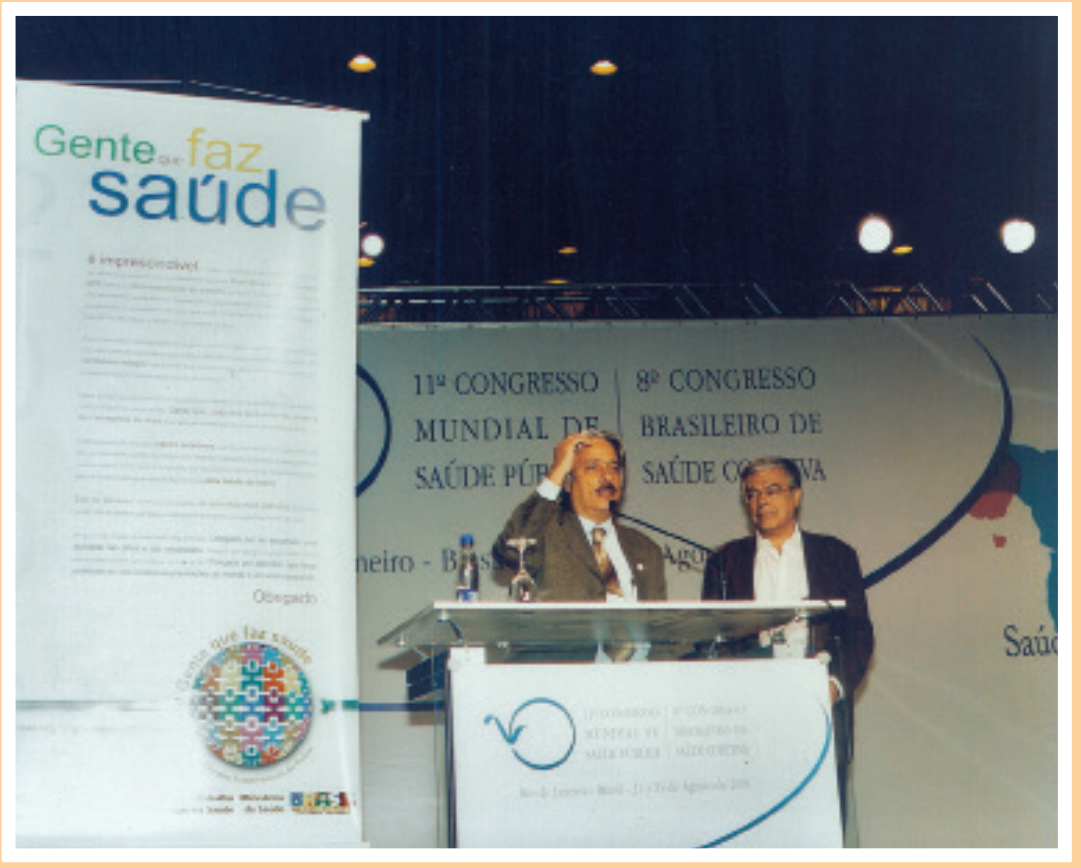

Paulo Gadelha e Hesio Cordeiro no $11^{\circ}$ Congresso Mundial de Saúde Pública/ $8^{\circ}$ Congresso Brasileiro de Saúde Coletiva. Rio de Janeiro, ago. 2006. Acervo COC/Fiocruz.

$11^{\circ}$ Congresso Mundial de Saúde Pública/ $8^{\circ}$ Congresso Brasileiro de Saúde Coletiva. Rio de Janeiro, outubro de 2006. Da esquerda para a direita: Ruiz Matos, Marcos Mandelli, Ricardo Scotti, Nelson Rodrigues dos Santos, Clara Charf, Hesio Cordeiro, José Paranaguá de Santana e Paulo Gadelha. Acervo COC/Fiocruz.

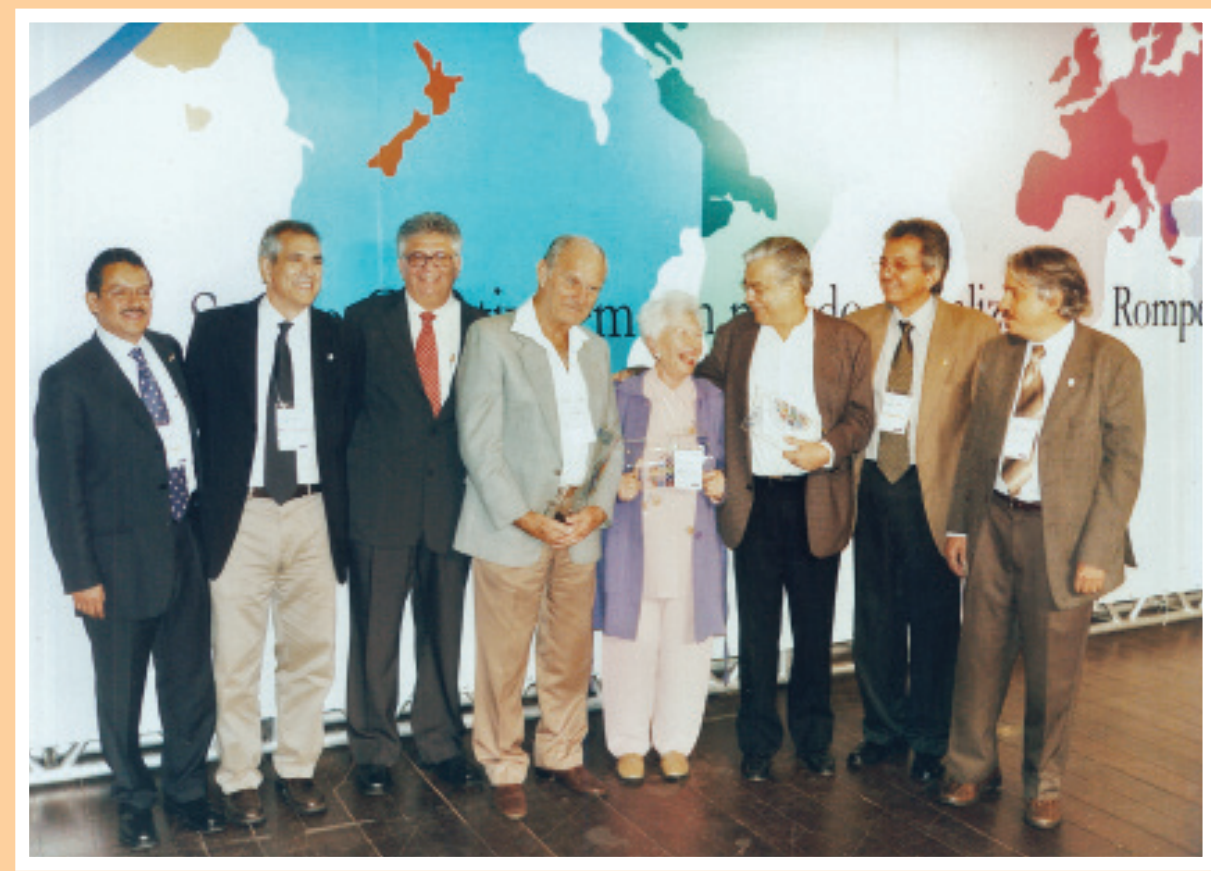



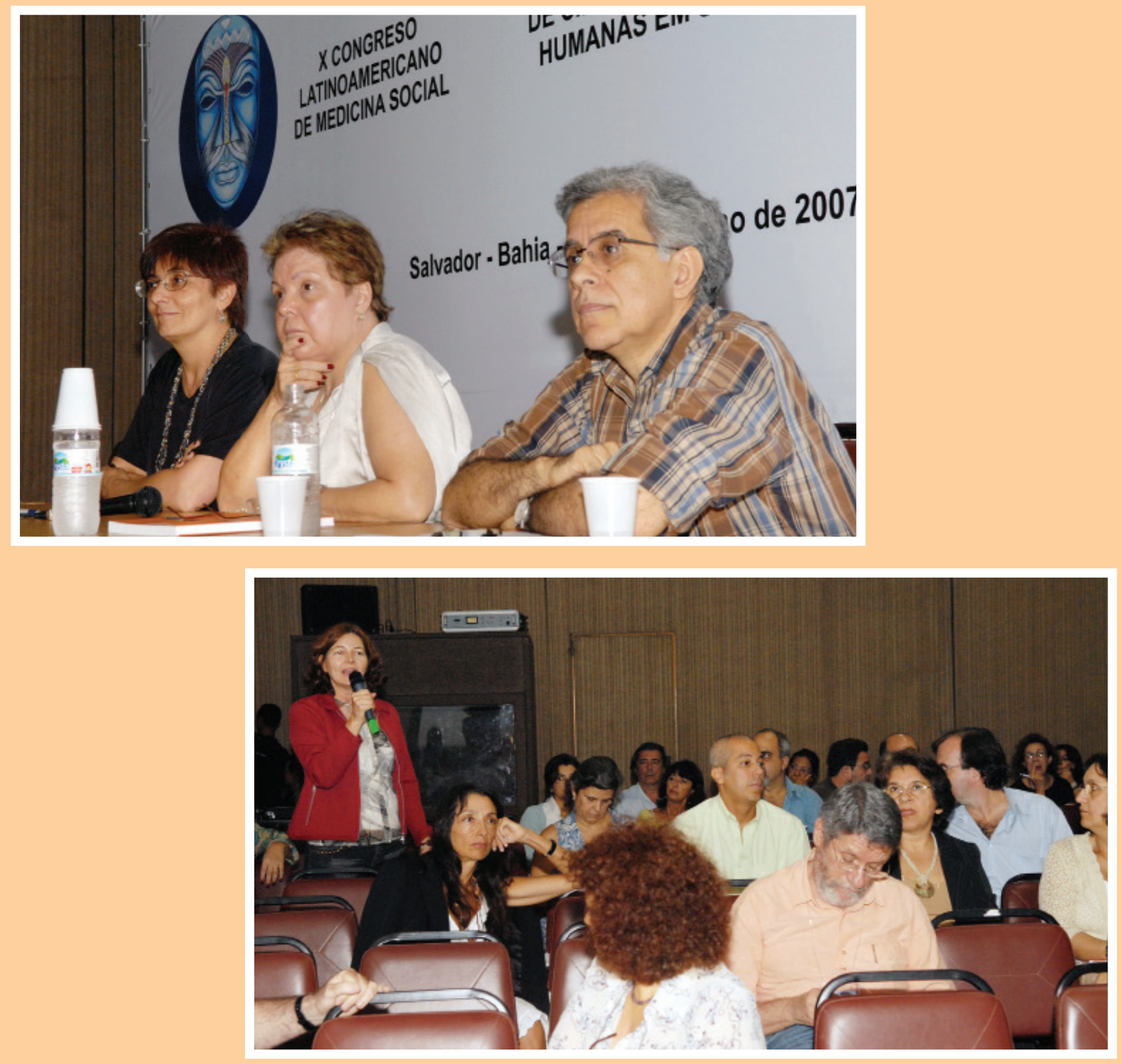

Reunião do Fórum de Coordenadores de PósGraduação no $10^{\circ}$ Congresso Latino-Americano de Medicina Social. Salvador, 13 a 18 de julho de 2007. Da esquerda para direita: Rita Barata, Maria Cecília de Souza Minayo e Maurício Lima Barreto. Acervo CCl/Ensp.

Reunião do Fórum de Coordenadores de PósGraduação no $10^{\circ}$ Congresso Latino-Americano de Medicina Social. Salvador, 13 a 18 de julho de 2007. Acervo CCI/Ensp.

Edição comemorativa do centésimo Boletim Abrasco, ago. 2008. Acervo Abrasco. 


\section{$A B R A A^{7} S C O$}

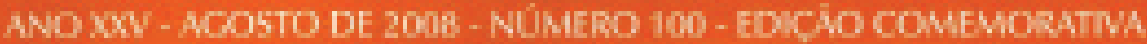
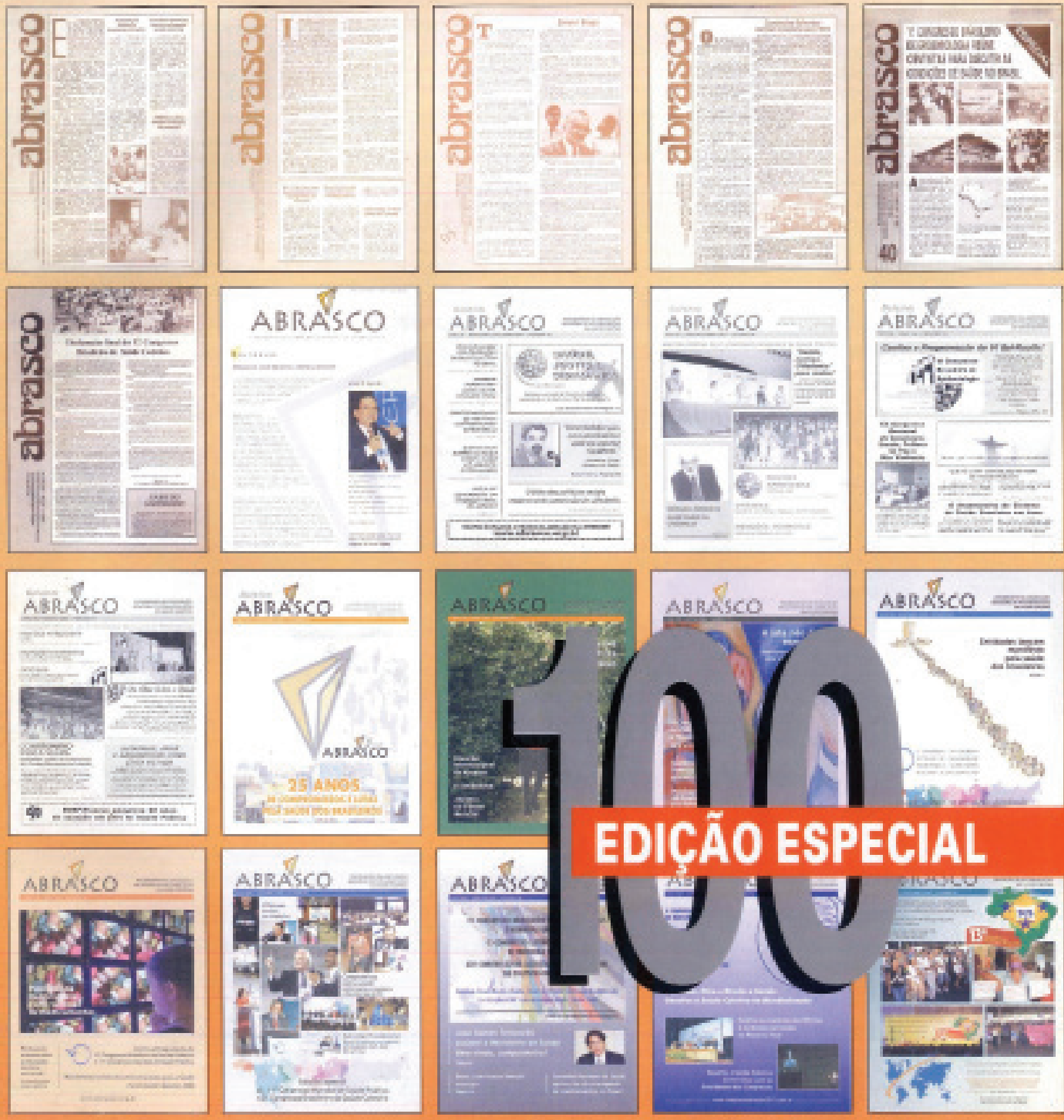


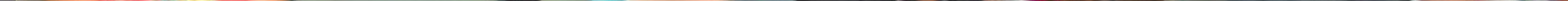




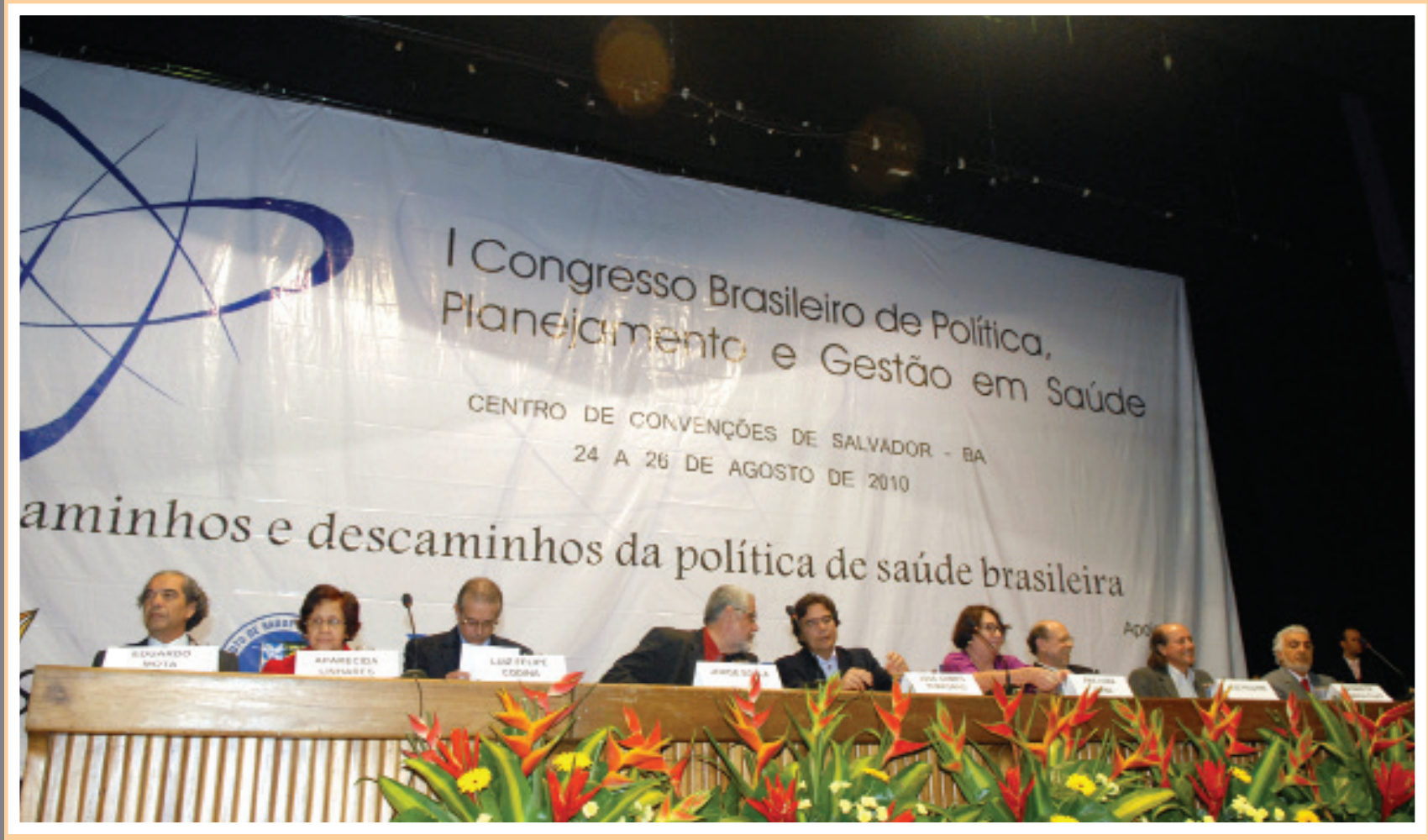

Eduardo Mota, Aparecida Linhares, Luiz Felipe Codina, Jorge Solla, José Gomes Temporão, Ana Luiza Viana, Luiz Augusto Facchini, Naomar Almeida Filho e José Carlos Brito no $1^{\circ}$ Congresso Brasileiro de Política,

Planejamento e Gestão em Saúde. Salvador, agosto de 2010. Acervo CCI/Ensp.

Jairnilson Paim, Hesio Cordeiro, Luiz Augusto Facchini e José Carvalho de Noronha no $1^{\circ}$ Congresso Brasileiro de Política, Planejamento e Gestão em Saúde. Salvador, agosto de 2010. Acervo CCl/Ensp.

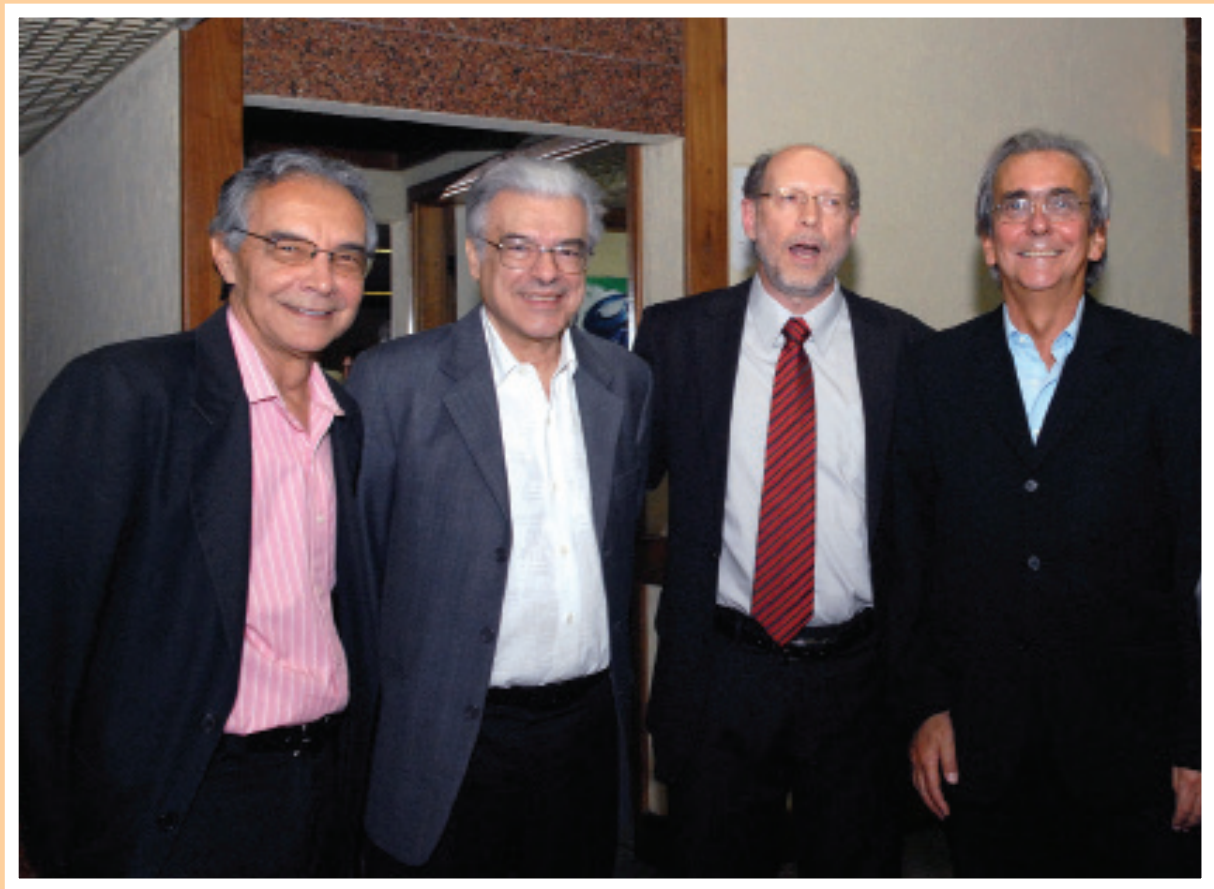




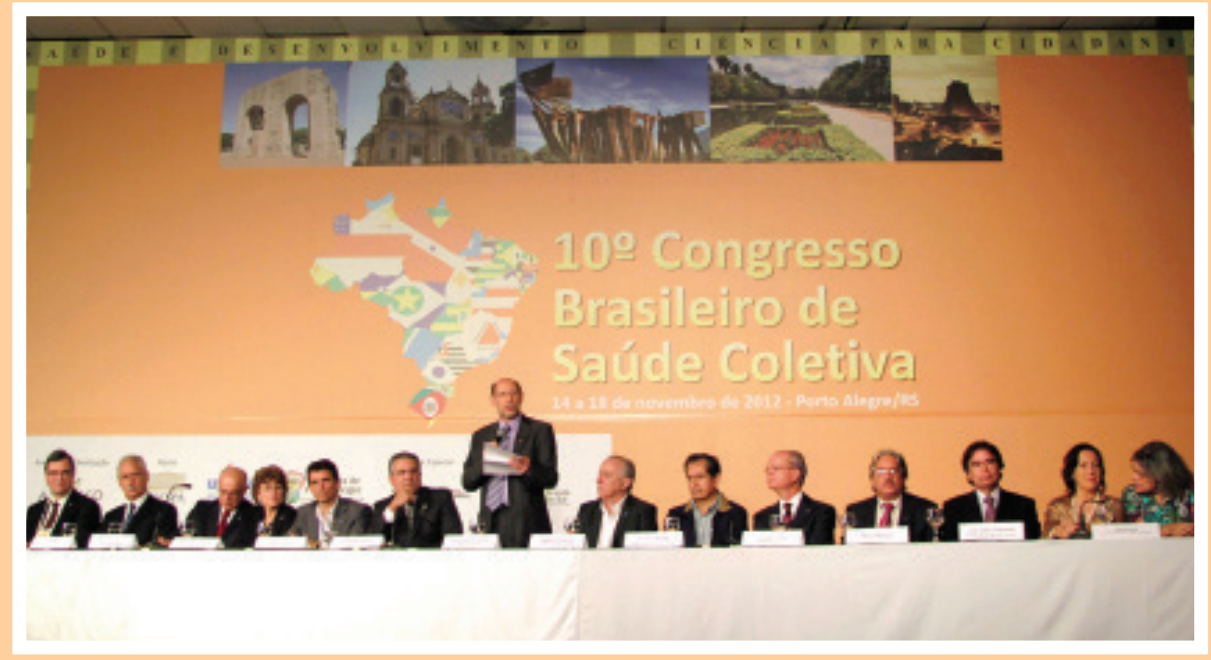

Mirta Roses, José Padilha, Luiz Augusto Facchini, Paulo Gadelha, José Gomes Temporão e Ligia Bahia no $10^{\circ}$ Congresso Brasileiro de Saúde Coletiva. Porto Alegre, novembro de 2012. Acervo CCl/Ensp.

Detalhe da Mesa de Abertura. $10^{\circ}$ Congresso Brasileiro de Saúde Coletiva. Porto Alegre, novembro, 2012. Acervo CCI/Ensp.

Luiz Augusto Facchini, presidente da Abrasco, no $10^{\circ}$ Congresso Brasileiro de Saúde Coletiva. Porto Alegre, novembro, 2012. Acervo CCl/Ensp.
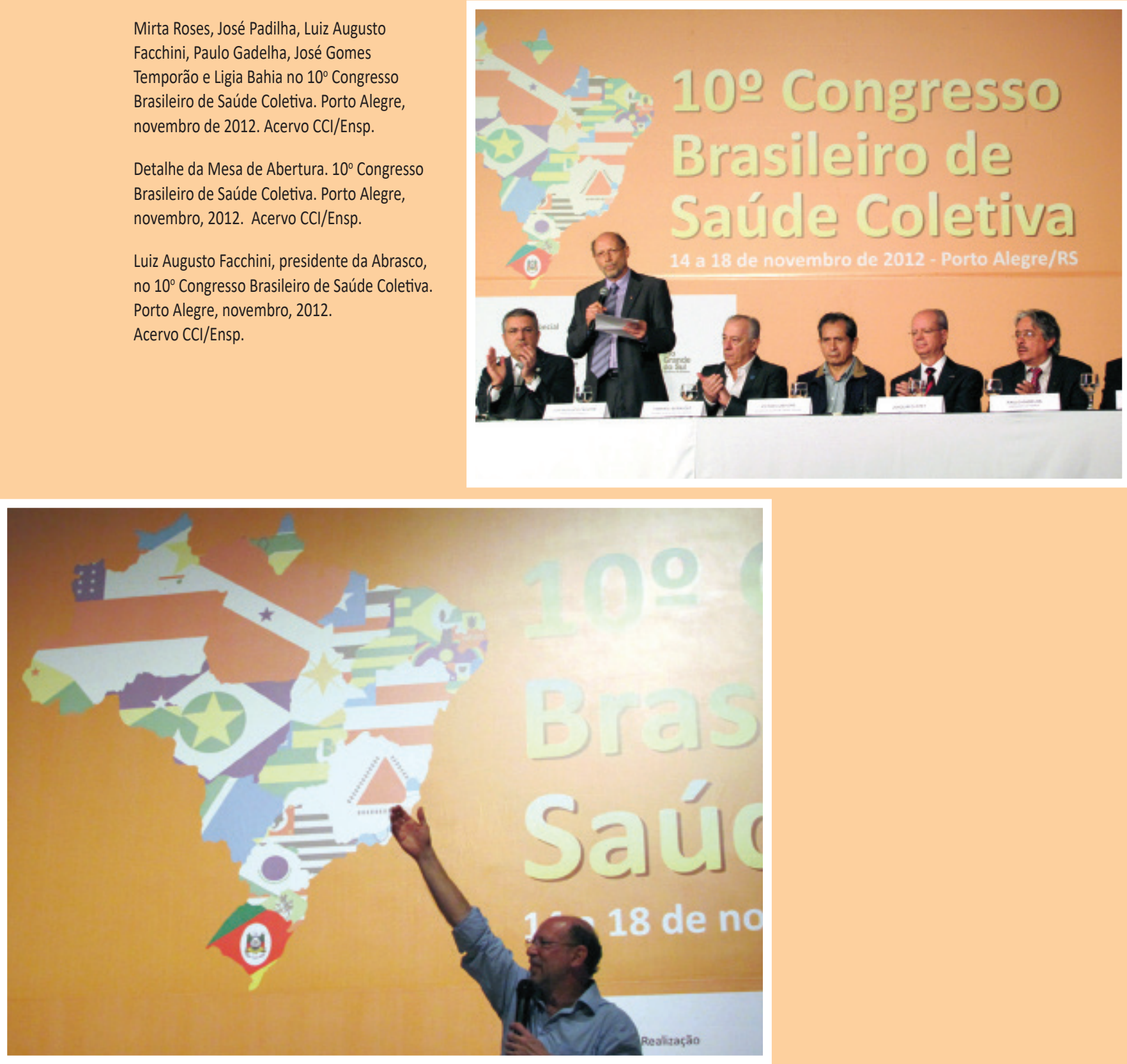


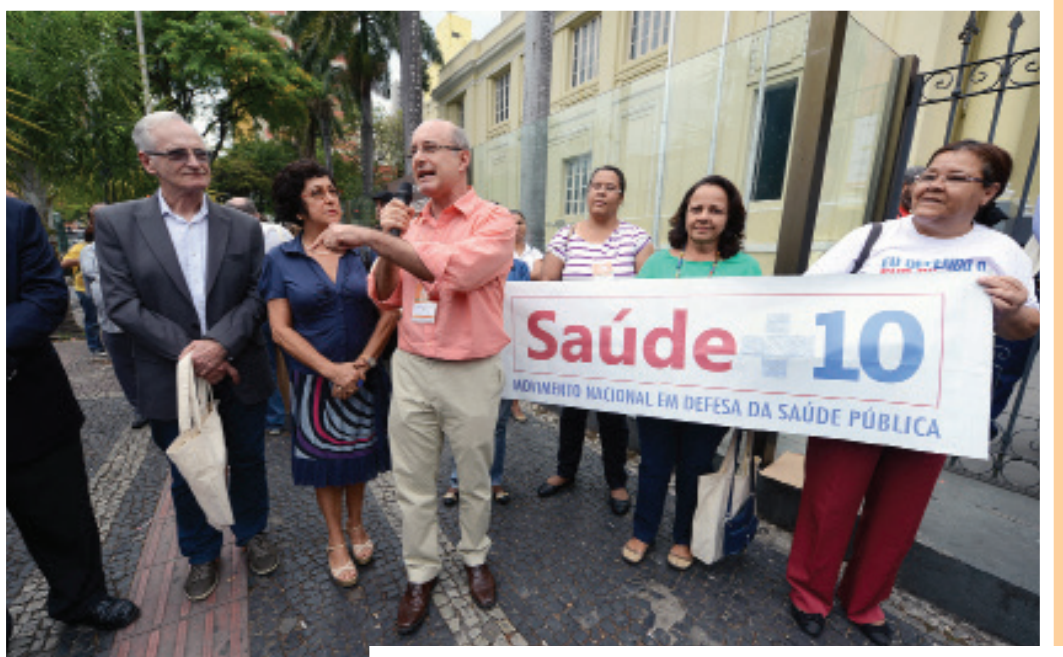

$2^{\circ}$ Congresso Brasileiro de Política,

Planejamento e Gestão em Saúde.

Belo Horizonte, 1 a 3 de outubro de 2013.

Luis Eugenio Portela F. de Souza, presidente da Abrasco, discursa em apoio ao Saúde +10 em manifestação realizada durante 0 congresso no Minascentro. Acervo $\mathrm{CCl} /$ Ensp.

$2^{\circ}$ Congresso Brasileiro de Política,

Planejamento e Gestão em Saúde. Belo Horizonte, 1 a 3 de outubro de 2013.

Abrasco apoia o Saúde +10 em manifestação realizada durante o congresso no Minascentro. Acervo CCl/Ensp.
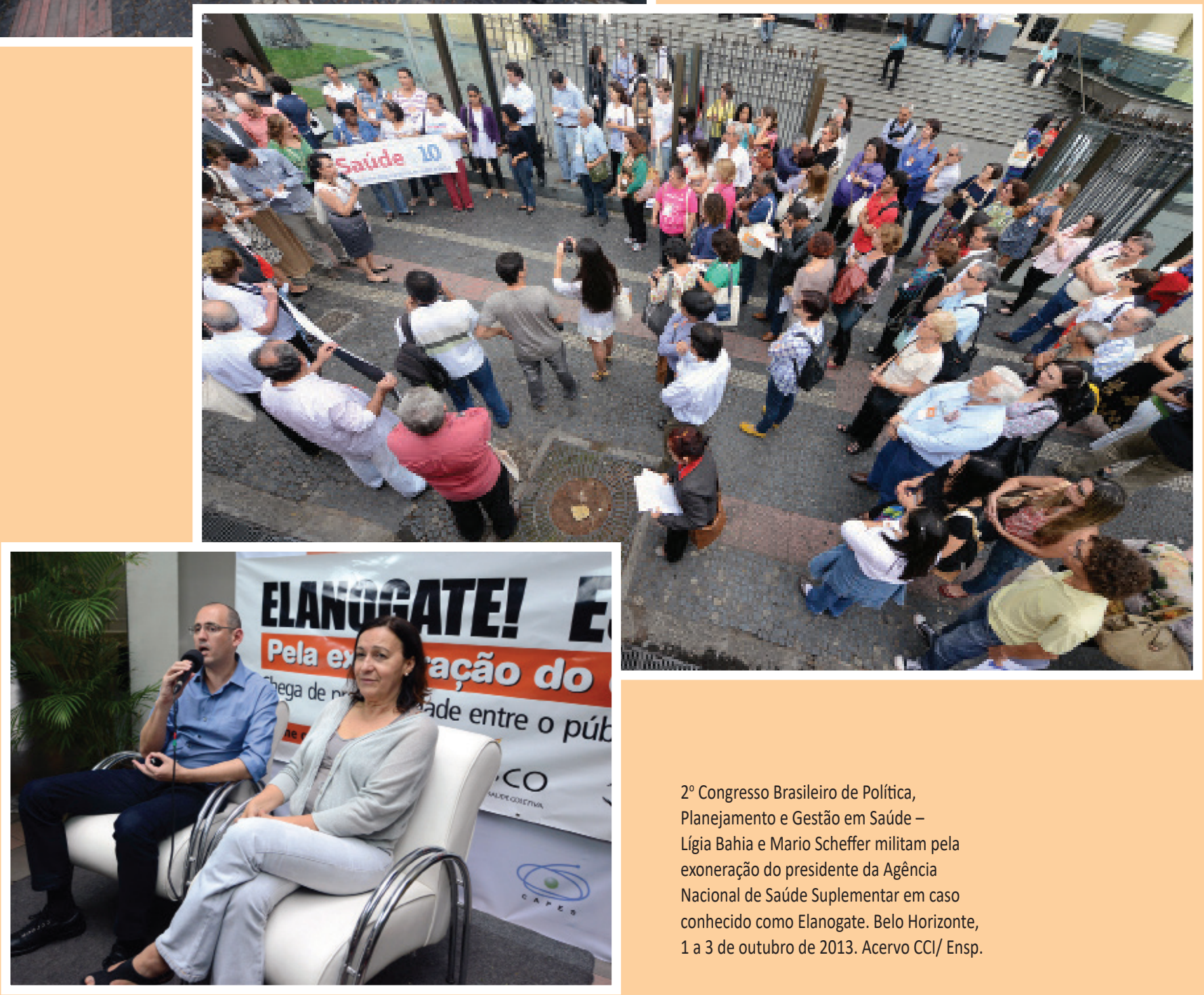

$2^{\circ}$ Congresso Brasileiro de Política, Planejamento e Gestão em Saúde Lígia Bahia e Mario Scheffer militam pela exoneração do presidente da Agência Nacional de Saúde Suplementar em caso conhecido como Elanogate. Belo Horizonte, 1 a 3 de outubro de 2013. Acervo CCI/ Ensp. 


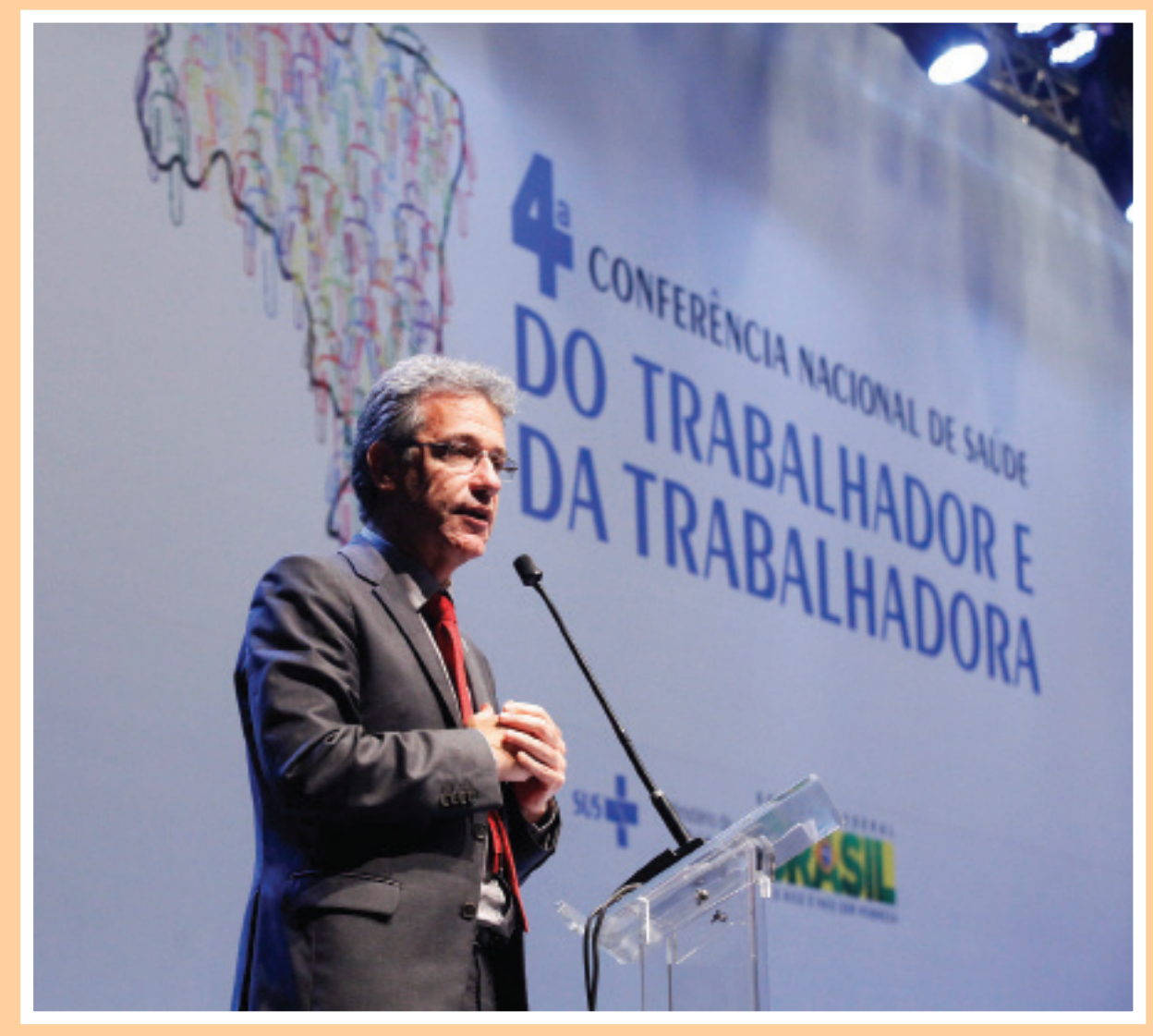

Arthur Chioro, ministro da Saúde, na $4^{\mathrm{a}}$ Conferência Nacional de Saúde do Trabalhador e Trabalhadora. Brasília, 15 a 18 de dezembro de 2014 . Acervo Conselho Nacional de Saúde.

Nas páginas seguintes:

Evento comemorativo dos 35 anos da Abrasco. Organização Pan-Americana de Saúde, Brasília, setembro de 2014.

Foto central: equipe atual, secretários e ex-secretários-executivos da Abrasco.

1 - José Paranaguá de Santana e Rita Barata

2 - Alvaro Matida e Moisés Goldbaum

3 - Moema de Siqueira, viúva de Benedictus Philadelpho de Siqueira $\left(1^{\circ}\right.$ presidente da Abrasco) e Jarbas Barbosa

4 - José da Silva Guedes

5 - Margareth Pessanha e José da Rocha Carvalheiro

6 - Paulo Gadelha

7 - Luiz Augusto Facchini

8 - Moisés Goldbaum

9-Sebastião Loureiro
10 - José da Rocha Carvalheiro

11 - Luiz Augusto Facchini, Moisés Goldbaum, Paulo Gadelha, Sebastião Loureiro e Luis Eugenio Portela F. de Souza

12 - Arlindo Fábio Gómez de Sousa

13 - João Carlos Canossa Mendes e Paulo Gadelha

14 - Arlindo Fábio Gómez de Sousa, Hesio Cordeiro, José Carvalho de Noronha, José da Rocha Carvalheiro e José da Silva Guedes

15 - Hesio Cordeiro

16 - Hesio Cordeiro, Paulo Gadelha, Sebastião Loureiro, Luis Eugenio Portela F. de Souza, Moisés Goldbaum, José Carvalho de Noronha, Luiz Augusto Facchini, Arlindo Fábio Gómez de Sousa, José da Rocha Carvalheiro, José da Silva Guedes

17- José Carvalho de Noronha 


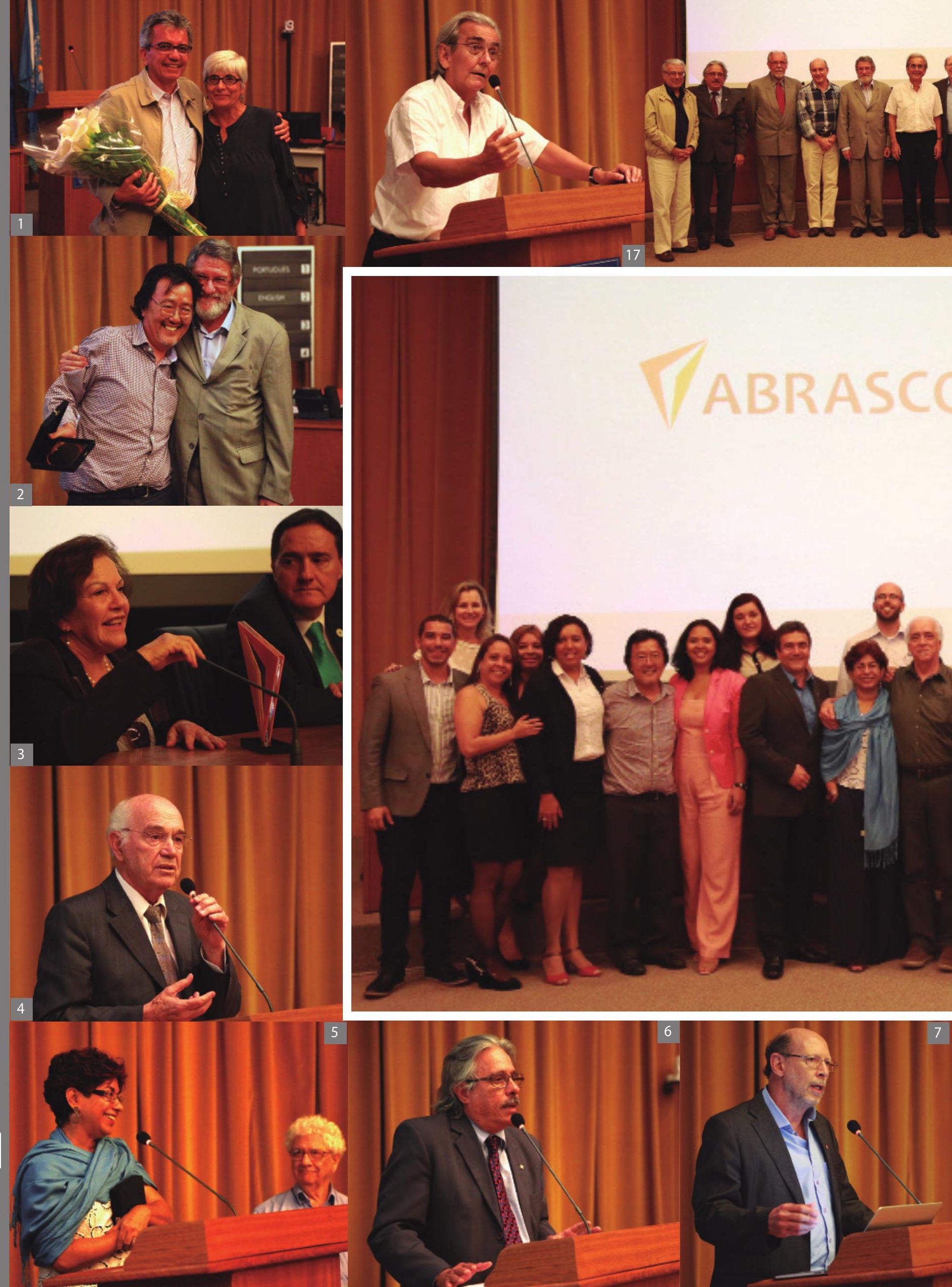


Hin

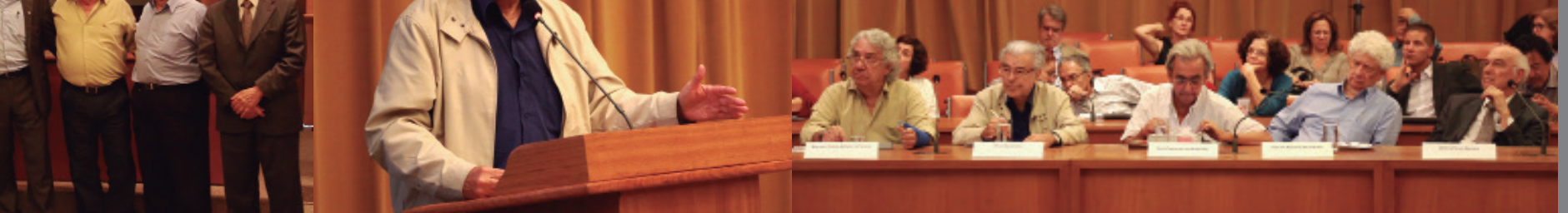

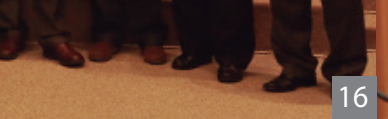

a. 15

29

A (1) 1 ?

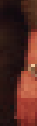

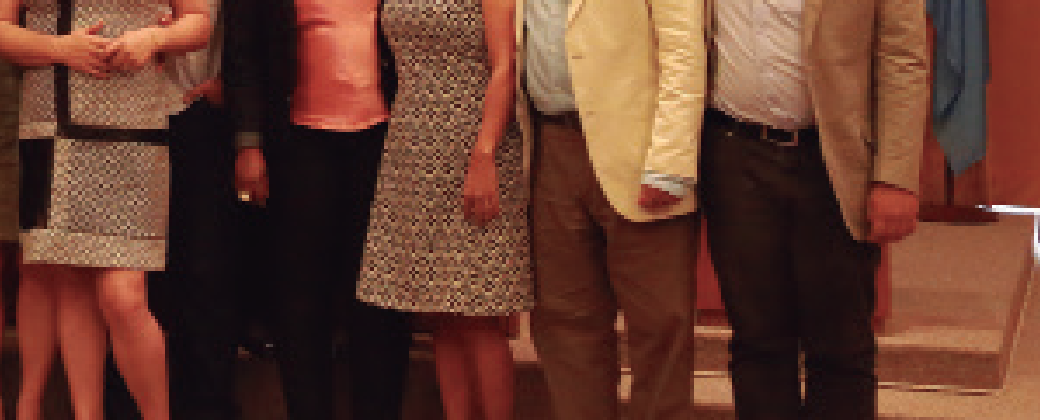

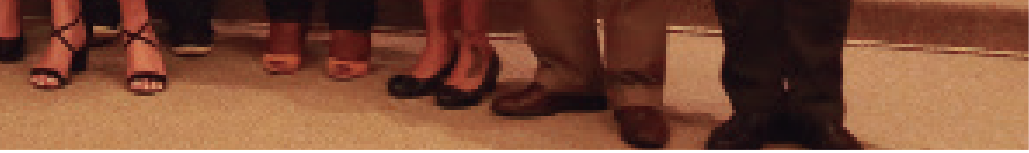
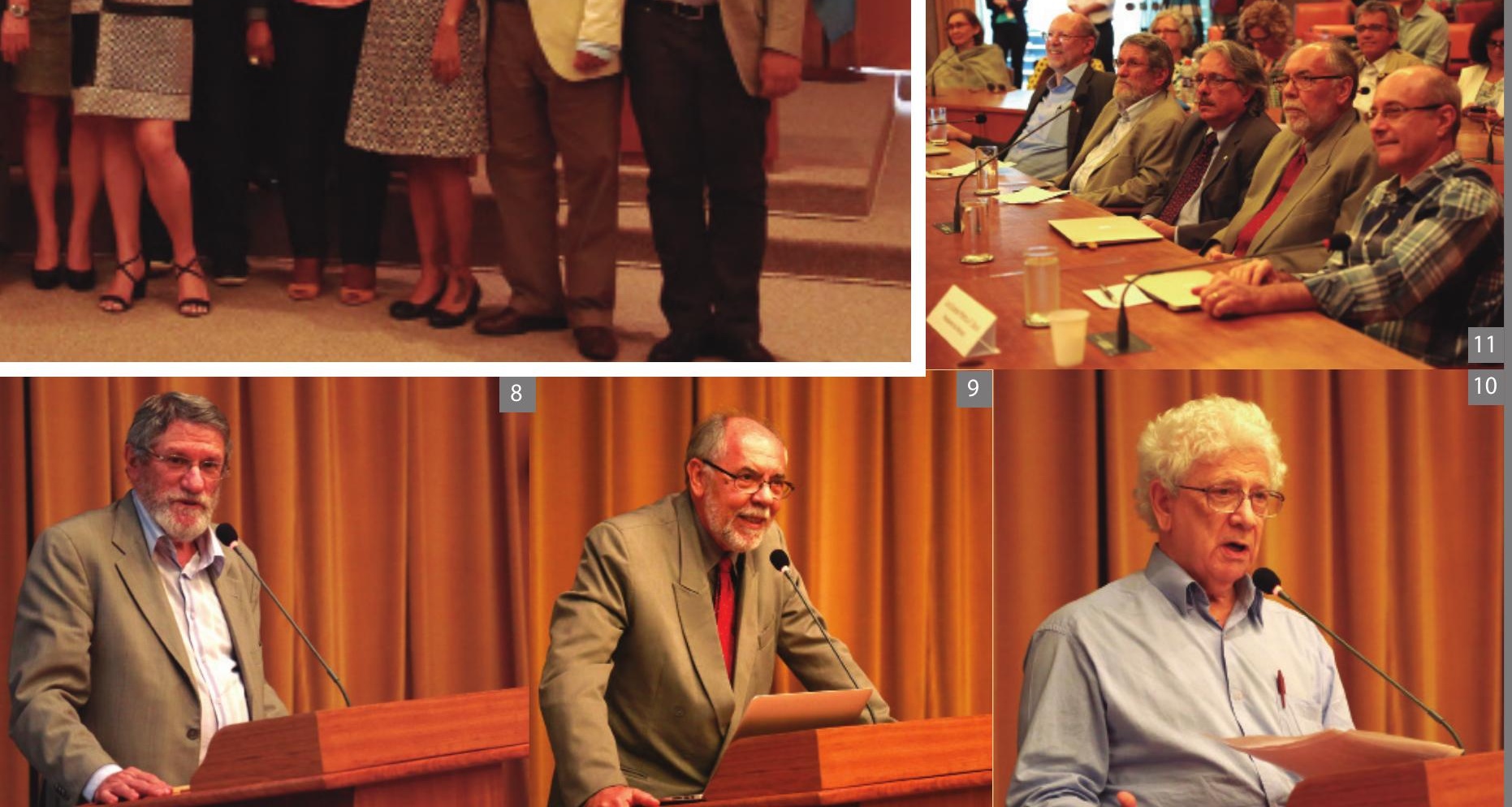

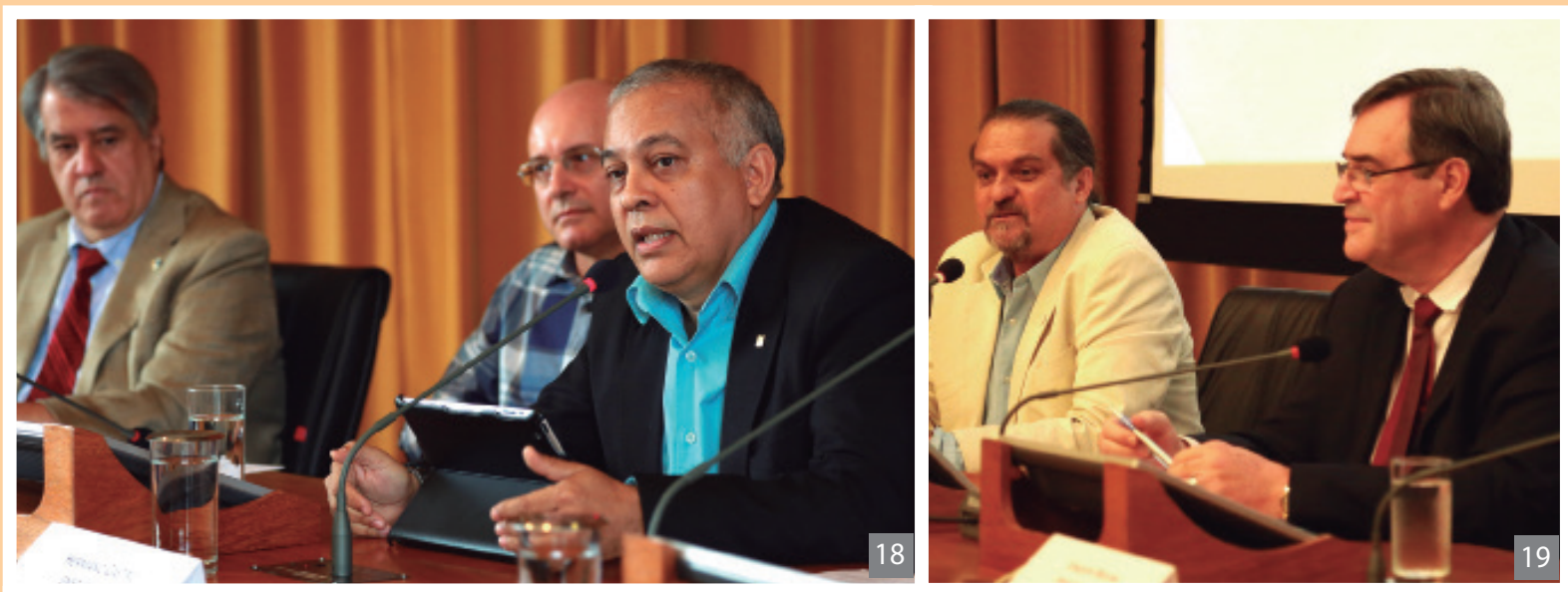

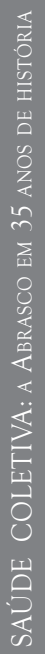

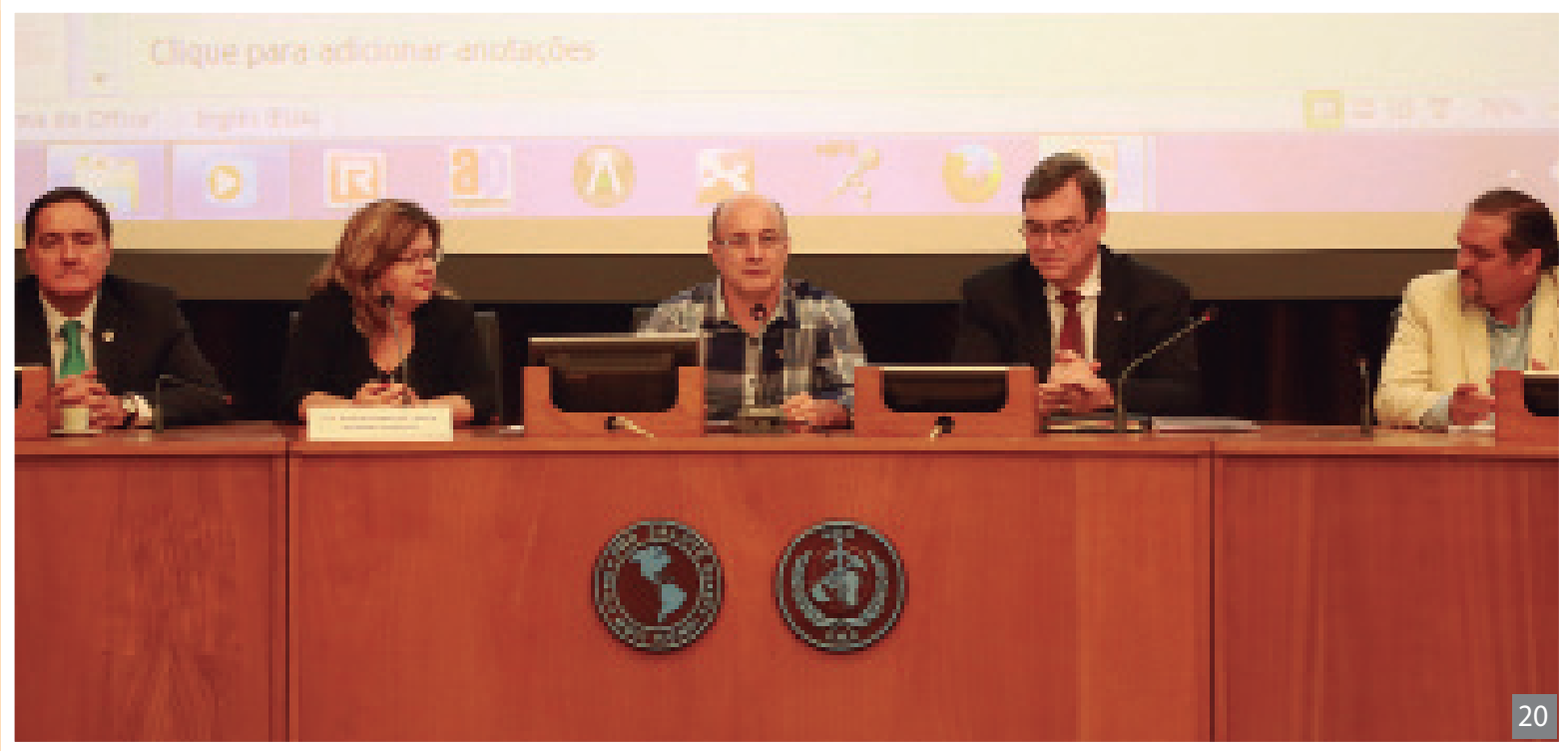

18 - Felix Rigoli, Luis Eugenio Portela F. de Souza e Hermano Castro

19 - Carlos Silva e Joaquín Molina

20 - Jarbas Barbosa, Ana Paula Menezes, Luis Eugenio Portela F. de Souza, Joaquín Molina e Carlos Silva 